\title{
Embryonic shell structure of Early-Middle Jurassic belemnites, and its significance for belemnite expansion and diversification in the Jurassic
}

\author{
LARISA A. DOGUZHAEVA, ROBERT WEIS, DOMINIQUE DELSATE AND NINO MARIOTTI
}

\section{LETHAIA}

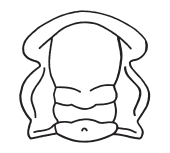

Doguzhaeva, L.A., Weis, R., Delsate, D. \& Mariotti N. 2014: Embryonic shell structure of Early-Middle Jurassic belemnites, and its significance for belemnite expansion and diversification in the Jurassic. Lethaia, Vol. 47, pp. 49-65.

Early Jurassic belemnites are of particular interest to the study of the evolution of skeletal morphology in Lower Carboniferous to the uppermost Cretaceous belemnoids, because they signal the beginning of a global Jurassic-Cretaceous expansion and diversification of belemnitids. We investigated potentially relevant, to this evolutionary pattern, shell features of Sinemurian-Bajocian Nannobelus, Parapassaloteuthis, Holcobelus and Pachybelemnopsis from the Paris Basin. Our analysis of morphological, ultrastructural and chemical traits of the earliest ontogenetic stages of the shell suggests that modified embryonic shell structure of Early-Middle Jurassic belemnites was a factor in their expansion and colonization of the pelagic zone and resulted in remarkable diversification of belemnites. Innovative traits of the embryonic shell of SinemurianBajocian belemnites include: (1) an inorganic-organic primordial rostrum encapsulating the protoconch and the phragmocone, its non-biomineralized component, possibly chitin, is herein detected for the first time; (2) an organic rich closing membrane which was under formation. It was yet perforated and possessed a foramen; and (3) an organic rich pro-ostracum earlier documented in an embryonic shell of Pliensbachian Passaloteuthis. The inorganic-organic primordial rostrum tightly coating the protoconch and phragmocone supposedly enhanced protection, without increase in shell weight, of the Early Jurassic belemnites against explosion in deepwater environment. This may have increased the depth and temperature ranges of hatching eggs, accelerated the adaptation of hatchlings to a nektonic mode of life and promoted increasing diversity of belemnoids. This study supports the hypothesis that belemnite hatchlings were 'a miniature of the adults'. $\square$ Belemnites, embryonic shell, expansion, inorganic-organic shell matter, Jurassic.

Larisa A. Doguzhaeva [larisa.doguzhaeva@nrm.se], Department of Palaeozoology, Swedish Museum of Natural History, PO Box 50007 Stockholm SE-104 05, Sweden; Robert Weis [rweis@mnhn.lu], Dominique Delsate [dominique.delsate@mnhn.lu], Musée national d'histoire naturelle, 25, Rue Münster Luxembourg L-2160, Luxembourg; Nino Mariotti [nino.mariotti@uniroma1.it], Dipartimento di Scienze della Terra, Università 'La Sapienza', P. le A. Moro 5 RomaI-00185, Italy; manuscript received on 20/02/2013; manuscript accepted on 16/05/2013.
The scant records of the Permian (Chen \& Sun 1982) and Triassic (Zhu \& Bian 1984; Iba et al. 2012) belemnite rostra apparently provide evidence for the limited habitats of pre-Jurassic belemnites, possibly caused by eustatically low sea levels. In the evolutionary history of belemnoids, the large-scale TriassicJurassic boundary extinction was followed by the Early Jurassic recovery. The first Jurassic (Hettangian) belemnites have been rare in collecting and have small taxonomic diversity as well as limited geographical distribution; the subsequent Sinemurian-Pliensbachian belemnites expose higher diversity and had broader habitats (Sachs 1961; Gustomesov 1977; Riegraf 1980; Chen 1982; Doyle 1987; Doyle et al. 1997; Weis \& Delsate 2005, 2006; Mariotti et al. 2010); during Jurassic and Cretaceous belemnites achieved a global expansion. The potential traits of a shell that would favour the successful adaptation of belemnites to a marine environment of Jurassic and, contra versa, the traits of the shell that would impede a global distribution of belemnoids in pre-Jurassic time have been inadequately known. The pro-ostracum represented a sole shell element that has been analysed in connection to global radiation of Jurassic belemnites (Doguzhaeva 2012; Doguzhaeva \& Summesberger 2012). The present article has the purpose to clarify the embryonic shell structure and its potential significance for the expansion and diversification of belemnites in the Jurassic. The embryonic shell structure has been deduced from the internal structures of the apical parts of shells and their chemical composition in the available Sinemurian-Bajocian (Early-Middle Jurassic) genera from Belgium, Luxembourg and France. 


\section{Historical background}

Two existing hypotheses differently describe the early ontogeny and the embryonic shell structure of belemnites. Quenstedt (1845-1849), Prell (1921), Naef (1922) and many authors after them (Jeletzky 1966; Bandel \& Boletzky 1979; Bandel et al. 1984; Bandel 1985; Ward \& Bandel 1987) assumed that the hatchlings of belemnites were 'miniatures' of the adults (for more information see Bandel et al. 1984). This view was later supported by direct observations on a pro-ostracum exposed in front of the protoconch in the juvenile shell of the Pliensbachian Passaloteuthis Lissajous 1915 (Doguzhaeva et al. 2003). Recent discovery of about $2 \mathrm{~mm}$ large hatchlings of Spirula Lamarck 1799 looking like adult individuals (Diekmann et al. 2002) showed that this extant shell-bearing decapod mollusc has a developmental behaviour hypothesized for the extinct belemnites (see above). Contrarily to this hypothesis, Stolley (1911), Müller-Stoll (1936), Hanai (1953) and Barskov (1973) assumed that the belemnites had a larval stage and a metamorphosis. According to Barskov (1973), the embryonic shell was external, formed by a protoconch with a single-layered shell wall; during the larval stage, the second layer of the protoconch wall was secreted and the larval shell become internal; the metamorphosis was correlated with the beginning of the rostrum secretion; the primordial rostrum was considered as a diagenetic formation.

\section{Material and methods}

\section{Specimens}

Among about a hundred tested Hettangian-Bajocian (Early-Middle Jurassic) belemnite shells, preserving an alveolus, from five localities of the Paris Basin (Fig. 1), 21 specimens of Nannobelus Pavlow 1914 (Sinemurian), Parapassaloteuthis Riegraf 1980 (Pliensbachian), Holcobelus Stolley 1927 (AalenianBajocian) and Pachybelemnopsis Riegraf 1980 (Bajocian) show the protoconch and the primordial rostrum, four of which preserved closing membrane and beginning of siphuncle and five showed partial pro-ostraca fused with the fossilized mantle. The specimens are stored at the Museum of Natural History in Luxembourg (MNHNL), with the exception of three specimens of Nannobelus, which are housed at the Swedish Museum of Natural History (NRM).

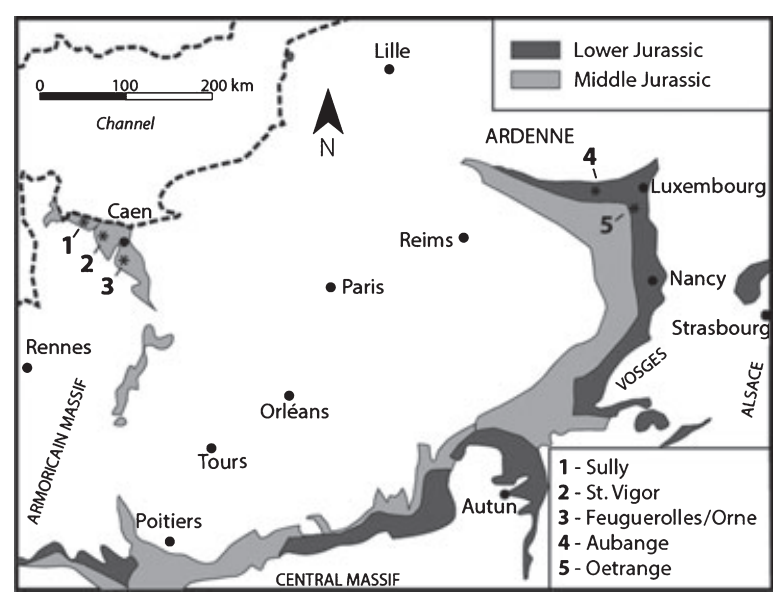

Fig. 1. Map of the Paris Basin showing the position of the cited localities marked by an asterisk (modified after Pomérol 1974).

\section{Morphological, ultrastructural and chemical analyses}

The gross morphology of the apical parts of the available shells and the median shell sections through the protoconch were examined using a Wild M400 light photo microscope (Zeiss, Germany). Then the ultrastructure and chemical composition of the primordial rostrum, protoconch wall, protoconch pockets, tubular and circular elements of unknown origin in the protoconch, diagenetic filling of protoconch, closing membrane, siphonal tube and its diagenetic filling, cameral deposits and the gaps between them in the first three chambers of the phragmocone, pro-ostracum fused with the fossilized mantle, rostrum and apical channel along the apical line of the rostrum were studied by means of a scanning electron microscope Hitachi-4300 equipped with an energy-dispersive spectrometer (EDS). For these purposes, the shell sections were etched with 1-5\% solution of hydrochloric acid for 5-10 seconds, glued with colloidal silver to the stubs, dried, coated with gold. Chemical analyses were performed at accelerating voltage of $15 \mathrm{kV}$, and energy calibration as measured on standard minerals of known accuracy was used. All elements were analysed, and no peaks were omitted. Data obtained for the listed above structures were compared.

\section{Measuring protoconch size}

The protoconch length is measured in three different ways: (1) on shell surface, as a distance between the top of the protoconch and its apertural constriction (L1); (2) in median sections lacking a closing membrane, as a distance between the top of the protoconch and a constriction between the protoconch 
Table 1. Protoconch maximum diameter (D) and length (L1, L2, L3) in Nannobelus, Parapassaloteuthis, Holcobelus and Pachybelemnopsis under study.

\begin{tabular}{|c|c|c|c|c|}
\hline Species & Dmax & Length L1/L2/L3 (mm) & Age & Locality \\
\hline Nannobelus sp. & 0.31 & $-/ 0.30 /-$ & Sinemurian & Tontelange/Belgium \\
\hline Nannobelus sp. & 0.32 & $-/ 0.24 /-$ & Sinemurian & Tontelange/Belgium \\
\hline Nannobelus sp. & 0.36 & $-/ 0.27 /-$ & Sinemurian & Tontelange/Belgium \\
\hline P. zieteni & 0.37 & $-/ 0.35 /-$ & Pliensbachian & Oetrange/Thionville \\
\hline P. zieteni & 0.39 & $-/ 0.38 /-$ & Pliensbachian & Oetrange/Thionville \\
\hline P. zieteni & 0.42 & $-/ 0.44 /-$ & Pliensbachian & Oetrange/Thionville \\
\hline P. zieteni & 0.46 & $-/ 0.42 /-$ & Pliensbachian & Oetrange/Thionville \\
\hline Holcobelus munieri & 0.32 & $-/ 0.33 /-$ & Aalenian/Bajocian & Normandy \\
\hline Holcobelus sp. & 0.45 & $-/ 0.38 /-$ & Aalenian/Bajocian & Normandy \\
\hline Holcobelus sp. & 0.38 & $-\mid 33 /-$ & Aalenian/Bajocian & Normandy \\
\hline Pachybelemnopsis sp. & 0.65 & $0.6 / 0.46 /-$ & Bajocian & Feuguerolles \\
\hline Pachybelemnopsis sp. & 0.67 & $-/ 0.59 /-$ & Bajocian & Feuguerolles \\
\hline P. cf. baculiformis & 0.46 & $-/ 0.36 /-$ & Bajocian & Sully \\
\hline P. apiciconus & 0.58 & $-/ 0.58 /-$ & Bajocian & Normandy \\
\hline P. apiciconus & 0.64 & $0.61 / 0.49 / 0.41$ & Bajocian & Normandy \\
\hline P. apiciconus & 0.65 & $-/ 0.53 /-$ & Bajocian & Normandy \\
\hline P. apiciconus & 0.65 & $0.54 /-/ 0.51$ & Bajocian & Belmont \\
\hline P. cf. verciacensis & 0.61 & $-/ 0.45 / 0.42$ & Bajocian & Nièvre \\
\hline
\end{tabular}

and phragmocone (L2); (3) in median sections showing a closing membrane, as a distance between the top of the protoconch and a point of a maximum curvature of closing membrane (L3). This is carried out because the protoconch length (Table 1) measured on the outer surface (L1) is larger than the length measured in median sections (L2, L3). The difference between the three measured lengths (L1, L2, L3) of the same protoconch achieves 30\% (Table 1). These data are important for analysis of protoconch sizes in evolution of belemnoids (see Tables 1, 5; Discussion).

\section{Geological setting and depositional environment}

The herein studied Early-Middle Jurassic belemnites originate from the north-eastern and western margins of Paris Basin (Fig. 1). The north-east Paris Basin corresponds today to the French and Belgian Lorraine, including southern Luxembourg. In this area, the Lower Jurassic beds start with the alternating carbonates and marls of the Hettangian and Sinemurian age, deposited in the sedimentological regime of the littoral zone (Lathuilière 2010). The Hettangian belemnites, found in the nearby Lorraine Hettangian, are rare and fall in the single genus Schwegleria Riegraf 1980 (Weis \& Delsate 2005; Delsate 2008). The Early Sinemurian shells of Nannobelus directly follow the belemnites referred to Schwegleria. The Nannobelus shells were sampled from the blue-grey marls of the Strassen Member (Semicostatum and Turneri Zones in south-east Belgium, near Arlon (see Boulvain et al. 2001). The Pliensbachian Parapassaloteuthis shells were collected from marls, containing carbonates and sandstones, which were deposited in the sedimentological regime similar to that in Hettangian and Sinemurian. Two outcrops that yielded the Pliensbachian belemnites (Aubange-Ottemt, south-east Belgium, and Oetrange, north-east France) are dated from the uppermost Pliensbachian, Spinatus Zone, by the means of ammonites Amauroceras ferrugineum (Simpson 1855) and Pleuroceras sp. The Aalenian-Bajocian Holcobelus and Bajocian Pachybelemnopsis shells were collected from the 'Oolithe ferrugineuse de Bayeux' Formation, at the 'classic', now inaccessible localities Sully and St. Vigor (Préat et al. 2000). Additional specimens have been recovered from the lower portion (Humphriesianum Zone) of the 'Oolithe ferrugineuse de Bayeux' Formation at Feuguerolles-sur-Orne.

\section{Observations}

\section{Internal apical shell structures}

Protoconch. - The protoconchs observed in Nannobelus (Fig. 2A-E), Parapassaloteuthis (Fig. 3A-F), Holcobelus (Fig. 4C, D, F) and Pachybelemnopsis (Figs 4A, B, E; 5A-F) are ovoid or spherical; the external surface is smooth. The protoconch wall is formed by the outer organic, prismatic and inner organic layers (Fig. 2C); it frays out at the corners between the protoconch and the phragmocone. The axes of the protoconch and the phragmocone form an angle. The range of the protoconch diameter is $0.31-0.67 \mathrm{~mm}$; the protoconchs with the smallest diameter are those of Nannobelus and with the 

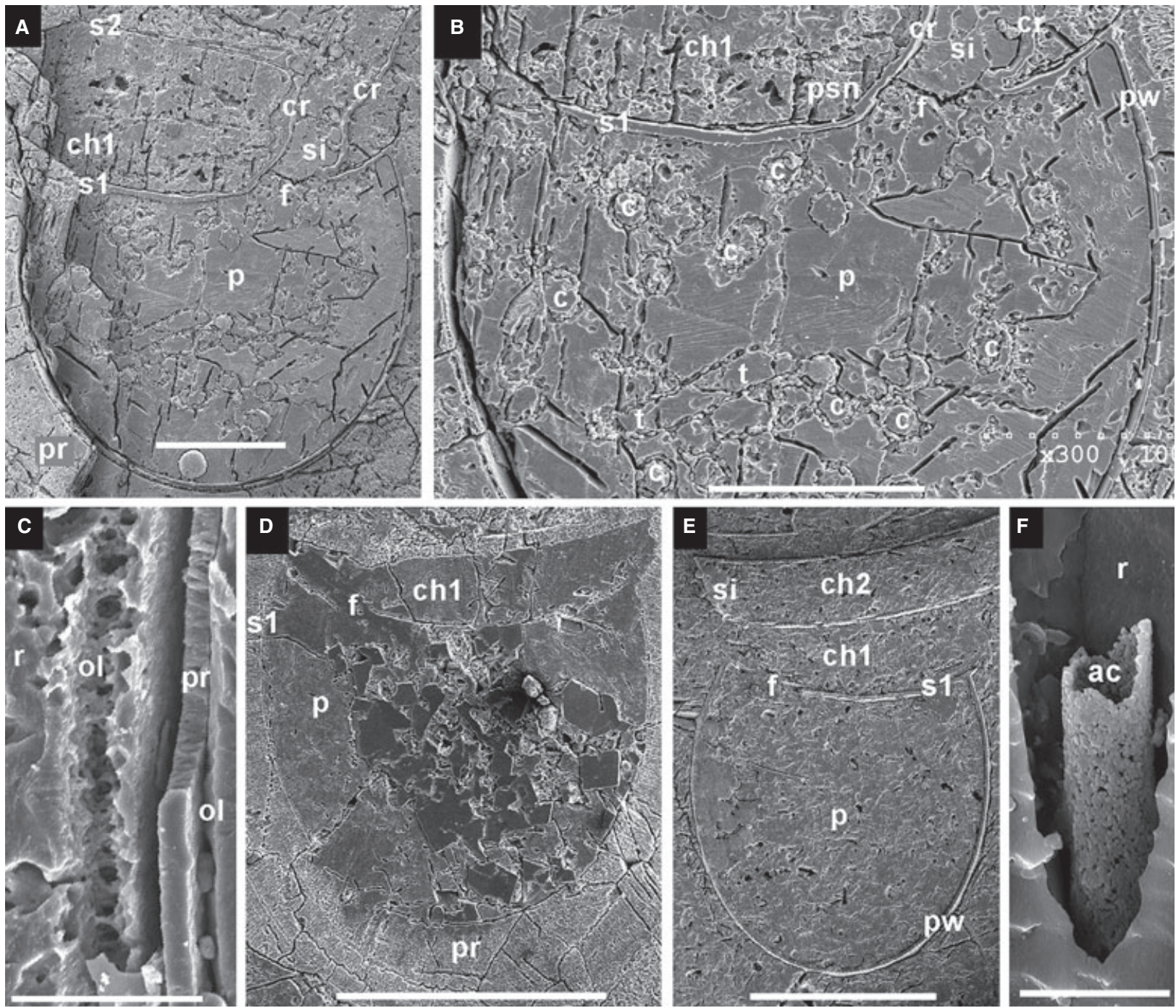

Fig. 2. Nannobelus sp., Sinemurian, Early Jurassic; Tontelange, Belgian Province of Luxembourg. A, B, E (NRM-PZ Mo. 161/183). A, median section of the protoconch and first chamber of phragmocone. B, enlarged detail of A showing structure less first septum perforated by a siphuncle, and numerous circular or tubular nano structures inside the protoconch. C, enlarged detail of B showing prismatic and originally organic layers of the protoconch wall. D (NRM-PZ Mo. 161/185), longitudinal section of a spherical protoconch and two septa of phragmocone; crystals of iron-dioxide marks possible site of septal foramen in first septum. E (NRM PZ-Mo. 161/184), longitudinal section showing an ovoid protoconch and first septa of phragmocone. F (NRM-PZ Mo. 161/186), an overall view caused by a longitudinal fracture of rostrum with the exposed apical channel with a granular wall inside the apical cavity of the rostrum. Abbreviations: ac, apical cavity; ap, apical channel; c, circular structures; ch1, first chamber of phragmocone; cr, connecting ring; ol, organic layer; p, protoconch; ph, phragmocone; pl, prismatic layer; pr, primordial rostrum; psn, prochoanitic septal neck; pw, protoconch wall; $r$, rostrum; s1, s2; first and second septa; si, siphuncle; t, tubular structures. Scale bars $=100 \mu \mathrm{m}, 100 \mu \mathrm{m}, 25 \mu \mathrm{m}, 250 \mu \mathrm{m}, 250 \mu \mathrm{m}, 2.5 \mu \mathrm{m}$, respectively.

largest diameter are those of Pachybelemnopsis; the former are about two times less than the latter (Table 1).

The protoconch pockets observed in Holcobelus (Fig. 4C, D) and Pachybelemnopsis (Fig. 4A, E) represent a pair of longitudinal lens-like compartments formed by invagination of the inner organic layer of the protoconch wall in the middle part of the protoconch length; they are hollow or filled with sediment and have variable shape and size.

Numerous nano-tubes within the protoconch of unknown origin observed in Nannobelus (Fig. 2B) - in median shell section look like tubular, circular or elliptic structures about $20-30 \mu \mathrm{m}$ in diameter; their wall is about $2-3 \mu \mathrm{m}$ thick and formed by grains of calcium phosphate; in this respect, they are similar to the apical channel (Fig. 2F).

Closing membrane. - The closing membrane, observed in four specimens of Pachybelemnopsis (Figs 4A, B; 5B-E; 6B, C; 8), represents a concave structure above the aperture of the protoconch attached to the shell wall at the corners between the protoconch and the phragmocone. It has an 

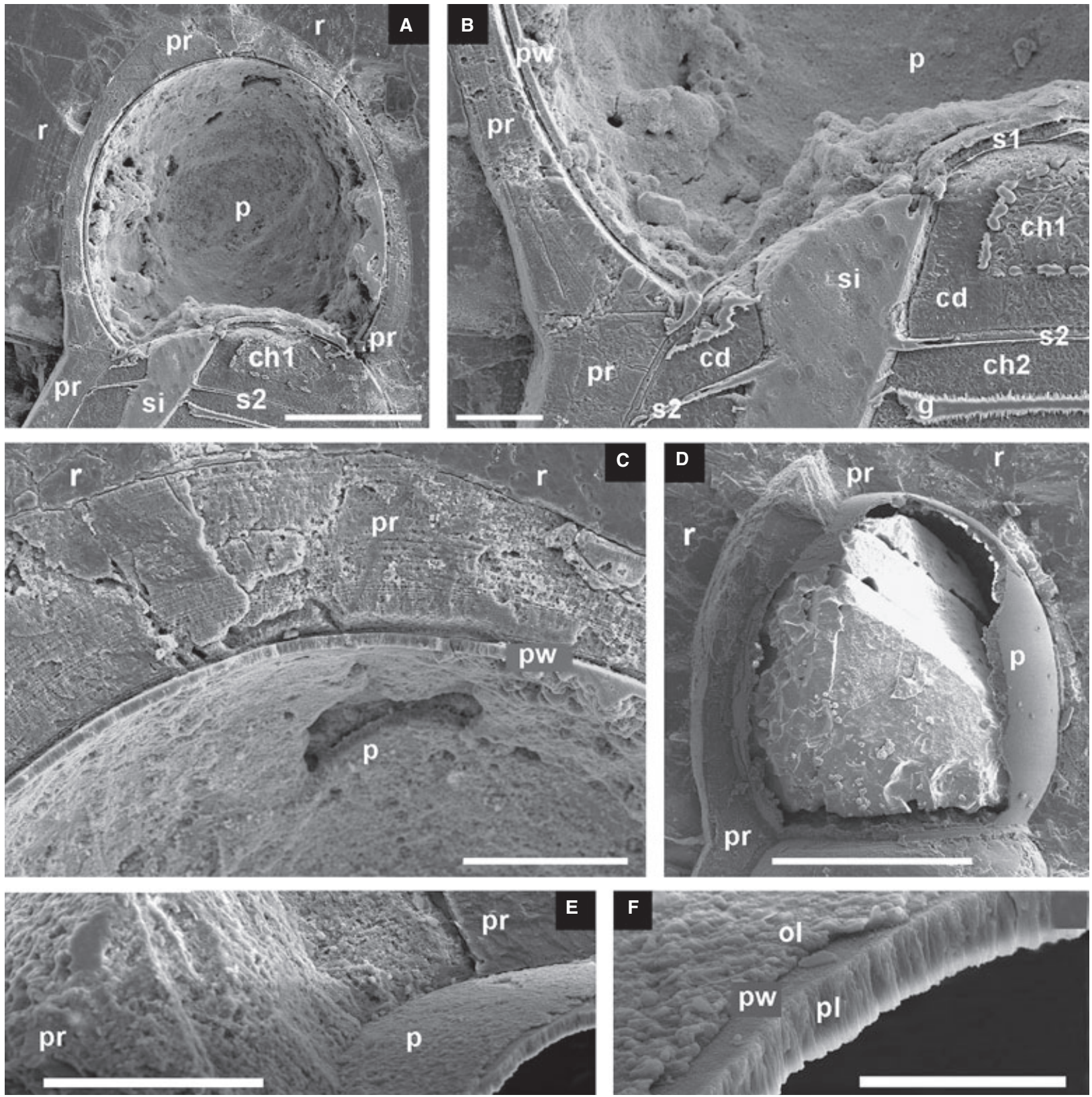

Fig. 3. Parapassaloteuthis zieteni, Pliensbachian, Early Jurassic; Oetrange/Thionville, France. A-C (MNHNLBEL121a). A, median section exposing the hollow spherical protoconch, first chambers of the phragmocone, and a primordial rostrum. B, enlarged detail of A to show the tubular first segment of siphuncle. C, enlarged detail of A to show finely laminated loosely mineralized primordial rostrum (top) and thin prismatic layer of the wall of protoconch (below). D-F (MNHNLBEL229). D, an overall view caused by a longitudinal fracture of rostrum with the exposed ovoid protoconch and primordial rostrum; the protoconch exposes a smooth outer surface and a large diagenetical crystal inside. E, enlarged detail of D to show finely laminated primordial rostrum at the top of the protoconch. F, enlarged detail of $\mathrm{E}$ showing prismatic and irregularly mineralized apparently non-biomineralized outer layers of the protoconch wall. Scale bars $=200 \mu \mathrm{m}, 50 \mu \mathrm{m}, 50 \mu \mathrm{m}, 250 \mu \mathrm{m}, 50 \mu \mathrm{m}, 10 \mu \mathrm{m}$, respectively. Abbreviations: ch2, second chamber of the phragmocone; g, gap between the cameral deposits in the second chamber; for the other abbreviations see Fig. 2.

amorphous texture (Fig. 6B), a microglobular ultrastructure with globules being $<1 \mu \mathrm{m}$ in size (that is a microbial size) (Fig. 9A). In Pachybelemnopsis apiciconus (Blainville 1827) (MNHNL BEL224), the closing membrane is strongly concave adapically and shows a tiny sub-ventral foramen edged with a retrochoanitic neck (Fig. 6B, C). The foramen is
$0.02 \mathrm{~mm}$ in diameter, which is in 2.5 times less than the septal foramen in the first septum. In P. apiciconus (MNHNL BEL220), the closing membrane shows a sub-ventral foramen lacking a neck (Fig. 5B-E). The foramen is $0.03 \mathrm{~mm}$ in diameter, which is slightly less than the diameter of the septal foramen of the first septum in this specimen. The 

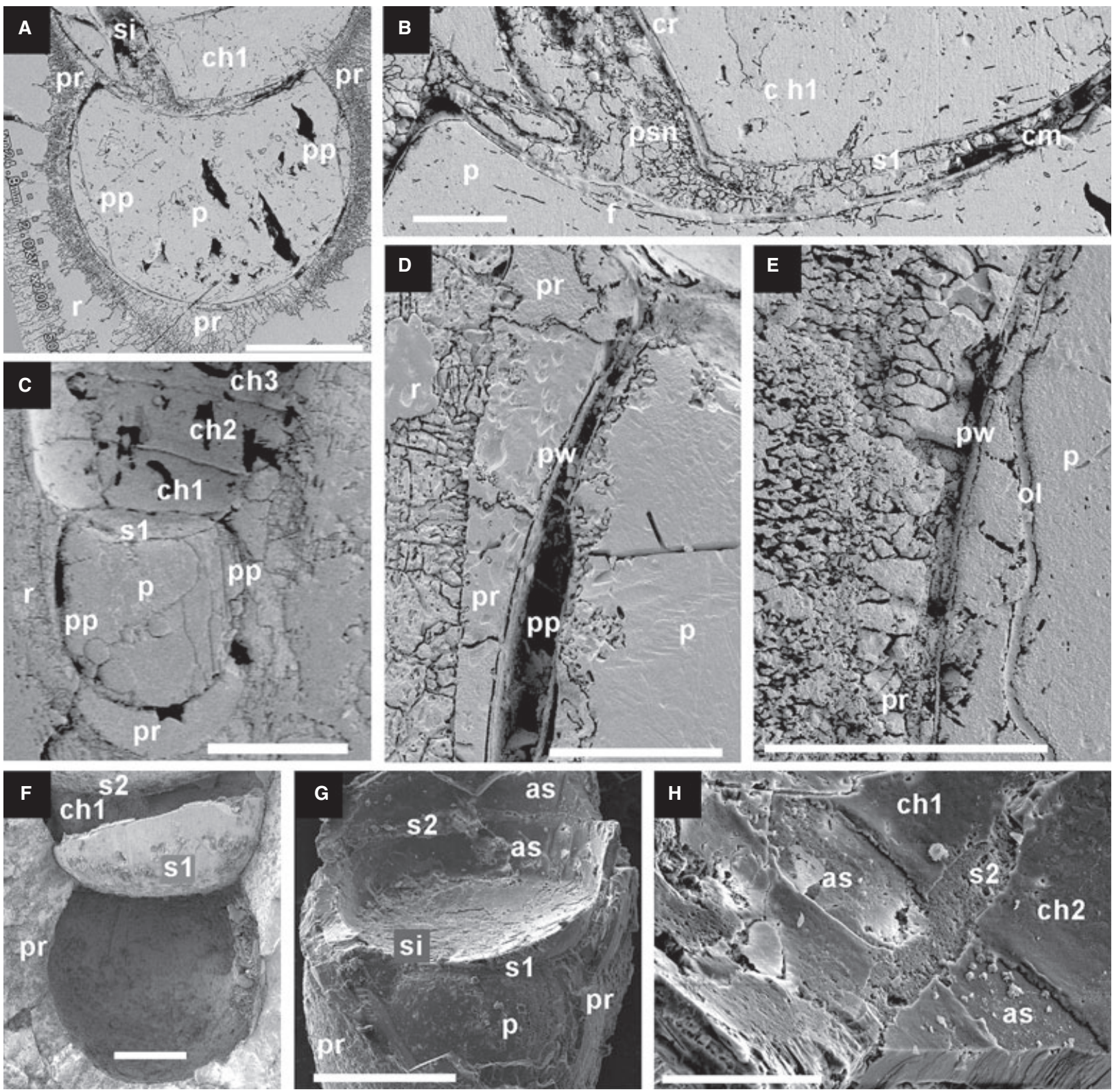

Fig. 4. A, B, E, Pachybelemnopsis cf. verciacensis (MNHNL BEL221), Bajocian, Middle Jurassic; Nièvre, France. A, median section of the spherical protoconch, first chamber of the phragmocone, and a rounded primordial rostrum. B, enlarged detail of A showing first prochoanitic septal neck and foot-like beginning of siphuncle. E, enlarged detail of A to show the protoconch pocket. C, D, F-H. Holcobelus munieri, Aalenian-Bajocian, Middle Jurassic; Normandy, France. C, D (MNHNL BEL227). C, medial section of the ovoid protoconch coated with a primordial rostrum, and the inner surface of first chambers of the phragmocone imprinted on rostrum. D, enlarged detail of $\mathrm{C}$ to show a protoconch pocket. F. (MNHNL BEL232), a spherical protoconch and the first and the second inclined septa preserved between hollow chambers; the primordial rostrum coats the protoconch and the phragmocone. G, H. (MNHNL BEL126). G, a capsulelike primordial rostrum with the protoconch partly exposed where the primordial rostrum is broken; the exposed inner surface of the first and second chambers shows dorsal unpaired attachment scars. $\mathrm{H}$, enlarged detail of $\mathrm{G}$ to show unpaired dorsal scars in first and second chambers. Scale bars $=250 \mu \mathrm{m}, 60 \mu \mathrm{m}, 50 \mu \mathrm{m}, 0.2 \mu \mathrm{m}, 50 \mu \mathrm{m}, 200 \mu \mathrm{m}, 150 \mu \mathrm{m}, 50 \mu \mathrm{m}$, respectively. Abbreviations: as, attachment scar; ch3, third chamber; cm, closing membrane; cr, connecting ring; pl, prismatic layer of the protoconch wall; pp, protoconch pocket; psn, prochoanitic septal neck; rsn, retrochoanitic septal neck; for the other abbreviations see Figs 2, 3.

closing membrane of this specimen shows peaks of $\mathrm{P}$ in any points but the foramen (Fig. 8). In P. cf. verciacensis (Lissajous in Grossouvre 1919) (MNHNL BEL221), the closing membrane exhibits some destruction in front of the septal foramen in a potential place of the foramen (Fig. 4A, B). The destruction might be caused by shell section crossing the periphery of the foramen and neck.

The closing membrane is missing in Nannobelus. This is unlikely to be the result of poor preservation as the connecting rings, ultrastructurally similar to the closing membrane, are not destroyed. These 

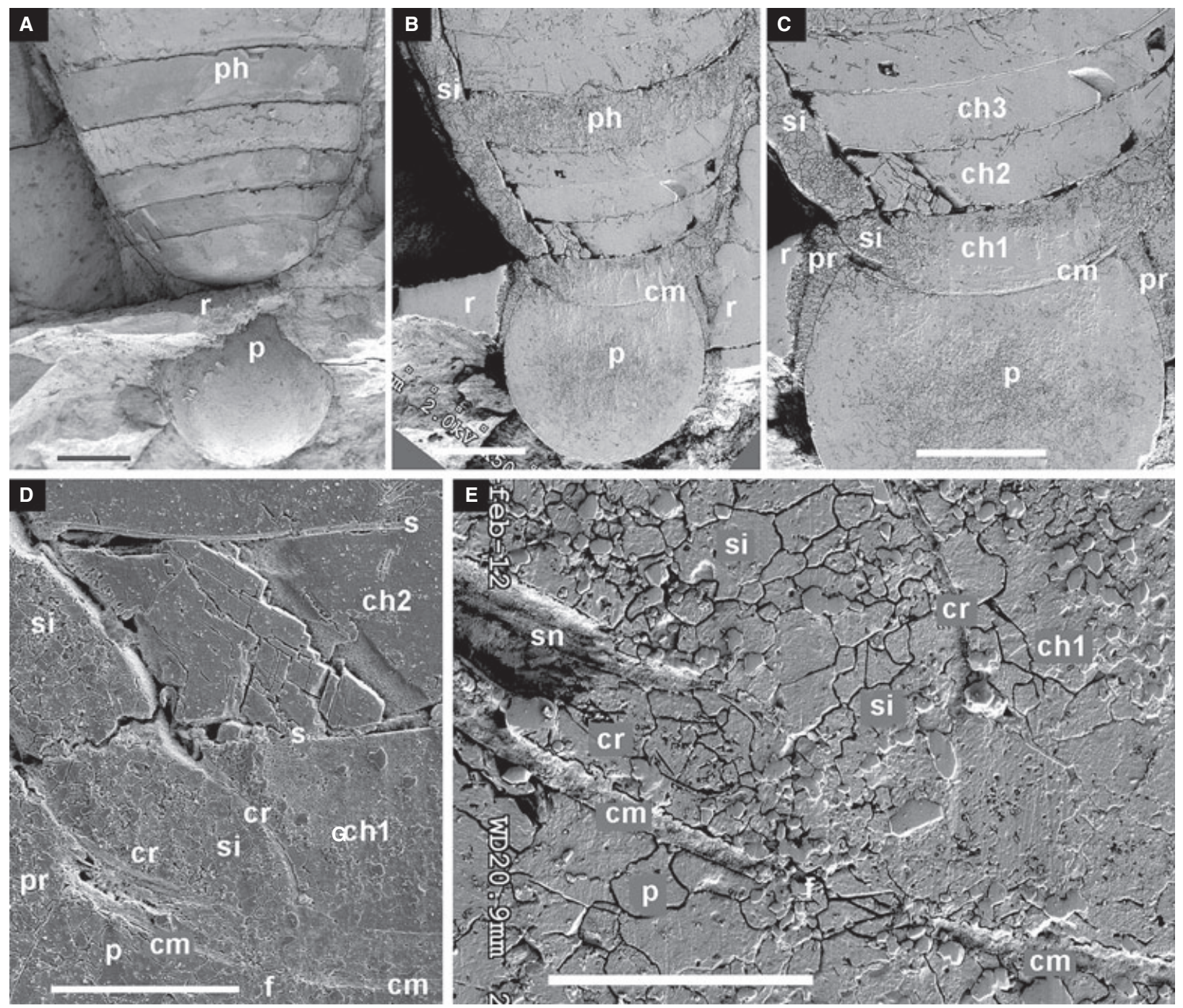

Fig. 5. Pachybelemnopsis apiciconus (MNHNL BEL220), Bajocian, Middle Jurassic; Belmont, France. A, an overall view caused by a longitudinal fracture of rostrum with the exposed globular protoconch and the apical part of the phragmocone. B, median section of shell of A showing inclined septa and marginal siphuncle (to the left) in first chambers of the phragmocone and a closing membrane. C, enlarged detail of $\mathrm{B}$ to show a primordial rostrum around a protoconch. D, enlarged detail of $\mathrm{C}$ to show the very beginning of siphuncle. $\mathrm{E}$, enlarged detail of D showing the curved first segment of siphuncle in front of the foramen in closing membrane. Scale bars $=0.25 \mathrm{~mm}$, $0.25 \mathrm{~mm}, 0.5 \mathrm{~mm}, 125 \mu \mathrm{m}, 50 \mu \mathrm{m}$, respectively. Abbreviations: f, foramen; ms, mural part of septum; sn1, first septal neck; for the other abbreviations see Figs 2 .

observations favour the idea that the Early Sinemurian Nannobelus did not possess the closing membrane, and the protoconch of this genus was covered with the perforated septum (Fig. 2A, B, D, E). In the Late Pliensbachian Parapassaloteuthis, the first septum is irregularly mineralized (Fig. $8 \mathrm{~A}$ ), the organic layer on its adapical surface is distinct but the closing membrane is not recognized and possibly missing (Fig. 3A, B). In the Aalenian-Bajocian Holcobelus, the shell shows well preserved originally organic layer of the protoconch wall and the rarely preserved protoconch pockets, however, the closing membrane is not distinguished (Fig. 4C). Therefore, in spite of the fact that the presumably organic shell structures are well preserved in all studied genera, the closing membrane is missing in Nannobelus, Parapassaloteuthis and Holcobelus and present only in Pachybelemnopsis.

Phragmocone. - In Nannobelus (Fig. 2A, E) and in Parapassaloteuthis (Fig. 3A), the first chamber of the phragmocone is longer than the second one and is about 0.3 the length of the protoconch. The siphuncle is sub-marginal in the first chamber; the first segment of connecting rings is tubular. In Nannobelus, the connecting ring is attached on the outside of the first septal neck that is prochoanitic; next septal neck is retrochoanitic (Fig. 2B). In Parapassaloteuthis, the 

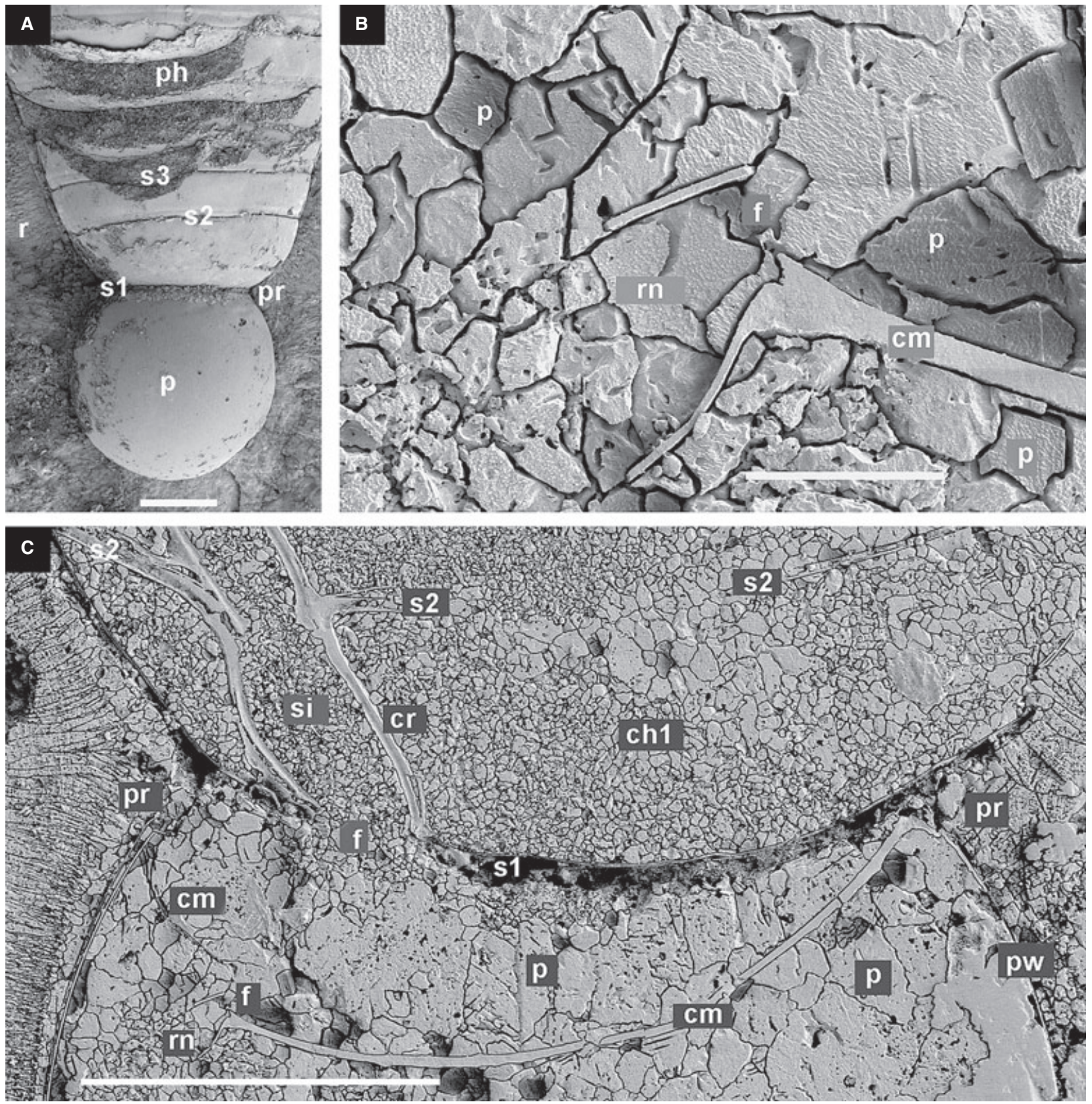

Fig. 6. Pachybelemnopsis apiciconus (MNHNL BEL224), Bajocian, Middle Jurassic; St. Vigor, Normandy, France. A, an overall view caused by a longitudinal fracture of rostrum with the exposed the globular protoconch and the phragmocone; first three septa are inclined; next septa are getting perpendicular to the phragmocone axis; and the fourth and fifth septa are not inclined. B, C, median section of the shell on A to show a contact between the protoconch (bottom) and phragmocone (top); a closing membrane exposes a ventral foramen in front of the foramen of the first septum; the foramen of the closing membrane is bordered with a retrochoanitic neck. Scale bars $=250 \mu \mathrm{m}, 25 \mu \mathrm{m}, 125 \mu \mathrm{m}$, respectively. Abbreviations: rn, reptrochoanitic neck; for the other abbreviations see Figs $2,4,5$.

siphuncle is swollen between the first and the second septa on the ventral side but straight cylindrical dorsally (Fig. 3A, B). The septal foramen of the first septum is about $0.05 \mathrm{~mm}$ in diameter. The first and several next septa are inclined dorsally; as a result, the chamber length on the dorsal side is longer than on the ventral side (Fig. 3A, B). In Holcobelus (Fig. 4C), the length of the first and the second chambers is about 0.4 protoconch length; the third chamber is slightly shorter than the previous ones (Fig. 4C). The first four to five septa are inclined dorsally; the next ones are perpendicular to the axis of the phragmocone (Fig. 4C, F). The siphuncle is not observed, however, the septal foramen of the first septum marks its ventro-marginal position from the beginning of the phragmocone (Fig. 4G). The unpaired dorsal rectangular attachment scars are present in the second and third chambers 
(Fig. 4G, H). They are about as long as the chamber; the width is about three times less than their length. The attachment scars represent shallow depressions rounded by the innermost layer of the chamber wall. The dorsal attachment scars of Holcobelus are similar in shape with the dorsal unpaired attachment scars of Spirula (Doguzhaeva 2000, pl. 2, figs 7, 8; Bandel \& Stinnesbeck 2006, fig. 3: 7). In Pachybelemnopsis apiciconus (with the exception of the specimen MNHNL BEL224), P. cf. verciacensis and Pachybelemnopsis sp., the first septum and the closing membrane are located extremely close to each other; the space between them can hardly be considered as a chamber; siphuncle is foot-like there (Figs 4A, B; 8). The siphuncle is sub-marginal, ventral; the septal foramen is $0.03 \mathrm{~mm}$ there; it is equal to the foramen of the closing membrane. The septal neck of the second septum is long, slightly shorter than the chamber length (Fig. 4A). In $P$. cf. verciacensis, the septal foramen is $0.09 \mathrm{~mm}$ in diameter. The second-fifth septa of the phragmocone are inclined dorsally; the following ones are perpendicular to the axis of the phragmocone, therefore, the first chambers are shorter ventrally and longer dorsally. In Parapassaloteuthis, the first and second chambers contain epiand hyposeptal cameral deposits separated by the slit-like gaps (Fig. 3A, B). The cameral deposits do not belong to the embryonic stage but were apparently secreted at later ontogenetic stages.

Primordial rostrum. - The primordial rostrum is distinguished from the rostrum by the ultrastructural differences between these two structures, visible in median shell sections. It tightly bounds the protoconch and the apical part of the phragmocone (Figs 2A, D; 3A-E; 4A, C, F, G; 6A, C). In Parapassaloteuthis (Fig. 3A-E), the primordial rostrum is rounded near the top of the protoconch where it has a thickness of about 0.15 protoconch length. It is thin on sides of the protoconch but swollen in the corners between the protoconch and the phragmocone; from this place forward the primordial rostrum represents a prismatic layer. Around the protoconch, the primordial rostrum is loosely mineralized and has a fine laminated ultrastructure (Fig. 3C). In Holcobelus (Fig. 4C, F, G), the primordial rostrum is rounded or conical near the top of the protoconch; it is about as thick as 0.3 protoconch length. In Pachybelemnopsis (Figs 4A, 6A), the primordial rostrum is short conical or rounded.

Pro-ostracum. - The pro-ostracum is not distinguished in the apical shell but is observed in about 20th-25th chambers of the phragmocone in two specimens of Parapassaloteuthis (MNHNL BEL235,
BEL059) and three specimens of Pachybelemnopsis (MNHNL BEL230, BEL224, BEL236). In Parapassaloteuthis zieteni (Mayer-Eymar 1884), the pro-ostracumis is distinguished due to longitudinal striation of the lateral fields and criss-cross pattern of the mantle attached to the lateral field (Fig. 9BD). In longitudinal shell sections, the pro-ostracum is located between the mural parts of the septa and primordial rostrum. The median shell section of Pachybelemnopsis (MNHNL BEL236) shows that the pro-ostracum is preserved in the middle part of the phragmocone but is destroyed in the apical direction; a hollow space left at place of the destroyed pro-ostracum comes to the protoconch. This is an indirect indication of the presence of the pro-ostracum in the embryonic shell.

\section{Energy-dispersive spectrometry data on chemical composition of shell}

Tested shells show regular phosphatization of structureless, apparently non-biomineralized, originally organic structures such as connecting rings, closing membrane, inner and outer layers of protoconch wall, adoral and adapical layers of septa, wall of nano-tubular structures within the protoconch, wall of apical channel, originally organic rich proostracum, and filling of siphuncle and gaps between epi- and hyposeptal cameral deposits. The listed above structures are also sporadically iron-oxidized (Tables 2-4; Figs 7, 8).

The highest values of $\mathrm{P}$ are revealed in the closing membrane $(16.9 \%)$, gaps between the epi- and hyposeptal cameral deposits (16.1\%), siphuncle in the first chamber $(12.3 \%)$, connecting rings $(12.2 \%)$, organic layer of protoconch wall $(10.5 \%)$ and organic layer of first septum (6.3\%) (Tables 2-4). The shell elements and sites listed above show also a varying amount of iron-oxides (Tables 2-4). The highest values of Fe are revealed in the pro-ostracum fused with the mantle tunic (62.9\%) (Tables 2, 4), siphuncle in the first chamber $(62.8 \%)$ (Table 4) and large dark spots in the protoconch (56.7\%) (Table 4). The highest values of $\mathrm{S}(4.4 \%)$ are recorded in the siphuncle (the first chamber) in association with a comparatively lower content of Fe (9.5\%) in Parapassaloteuthis (Table 2). One of three protoconchs of Holcobelus examined (MNHNL BEL227) is filled with transparent calcium carbonate but contains also large clusters of iron-oxide (Table 3).

The pattern formed by dark-brown Fe-containing material shows that it is distributed as if it would penetrate in the protoconch via the closing membrane. Judging on colour images the dark 'cloud' of 
Table 2. Chemical composition of the apical part of a shell (specimens from Oetrange/Thionville, France) and a pro-ostracum (specimens from Aubange, Belgian Province of Luxembourg) of Parapassaloteuthis zieteni, Pliensbachian, Early Jurassic (EDS data; in per cent to total weight).

\begin{tabular}{|c|c|c|c|c|c|c|c|}
\hline \multirow[b]{2}{*}{ Element (\%) } & \multicolumn{7}{|l|}{ Site } \\
\hline & Rostrum & Primordial rostrum & Septum & Proostracum & $\begin{array}{l}\text { Filling of } \\
\text { siphuncle } \\
\text { in first } \\
\text { chamber }\end{array}$ & $\begin{array}{l}\text { Cameral } \\
\text { deposits } \\
\text { (first, second } \\
\text { chambers) }\end{array}$ & $\begin{array}{l}\text { Gaps in } \\
\text { cameral } \\
\text { deposits }\end{array}$ \\
\hline Carbon & $6.9-10.3$ & $7.4-11.2$ & $7.3-10.6$ & $10.0-13.0$ & 6.7 & 8.6 & no data \\
\hline Nitrogen & $2.4-3.2$ & $5.2-10.0$ & $3.3-5.5$ & $6.1-6.8$ & 3.0 & 2.8 & no data \\
\hline Oxygen & $41.9-48.3$ & $46.3-52.9$ & $40.8-47.3$ & $54-61.3$ & 30.9 & 47.7 & 35.7 \\
\hline Fluorine & no data & no data & no data & no data & no data & no data & 7.7 \\
\hline Sodium & $0.1-0.3$ & $0.1-0.5$ & 0.4 & 0.3 & no data & no data & no data \\
\hline Magnesium & $0.2-0.4$ & $0.3-0.4$ & $0.2-0.4$ & 0.1 & no data & 0.6 & 0.2 \\
\hline Aluminium & no data & no data & no data & no data & no data & no data & no data \\
\hline Silicon & 0.2 & no data & 0.1 & 1.1 & $1.0-1.1$ & no data & no data \\
\hline Phosphorus & no data & no data & no data & no data & 12.3 & no data & 16.1 \\
\hline Sulphur & no data & no data & no data & no data & 4.4 & no data & no data \\
\hline Potassium & 0.8 & 0.2 & 0.2 & no data & no data & no data & no data \\
\hline Calcium & $38.3-46.9$ & $30.90-40.6$ & $41.0-46.2$ & $26.1-28.3$ & 33.2 & 40.0 & 40.3 \\
\hline Iron & no data & no data & no data & 62.9 & 9.5 & no data & no data \\
\hline Zinc & no data & no data & no data & no data & no data & no data & no data \\
\hline Strontium & $0.2-0.4$ & $0.2-1.3$ & $0.1-0.5$ & $0.4-0.7$ & no data & 0.3 & 0.1 \\
\hline Chlorine & no data & no data & no data & no data & no data & no data & no data \\
\hline Niobium & no data & no data & no data & no data & no data & no data & 0.5 \\
\hline Tin & no data & no data & no data & no data & no data & no data & 6.3 \\
\hline Platinum & no data & no data & no data & no data & no data & no data & 0.9 \\
\hline
\end{tabular}

Table 3. Chemical composition of the apical part of shell of the Aalenian-Bajocian Holcobelus munieri (EDS data; in per cent to total weight).

\begin{tabular}{|c|c|c|c|c|c|}
\hline \multirow[b]{2}{*}{ Element } & \multicolumn{5}{|l|}{ Site } \\
\hline & $\begin{array}{l}\text { Dark spots within } \\
\text { the protoconch }\end{array}$ & $\begin{array}{l}\text { Transparent filling } \\
\text { of protoconch }\end{array}$ & $\begin{array}{l}\text { Primordial } \\
\text { rostrum }\end{array}$ & $\begin{array}{l}\text { Organic layer of } \\
\text { first septum }\end{array}$ & $\begin{array}{l}\text { Protoconch } \\
\text { pocket }\end{array}$ \\
\hline Carbon & $5.8-6.7$ & 10.4 & 14.4 & 12.3 & 11.7 \\
\hline Oxygen & $35.1-36.0$ & 51.5 & 51.3 & 58.2 & 56.3 \\
\hline Sodium & no data & no data & no data & no data & 0.6 \\
\hline Aluminium & no data & no data & no data & no data & 0.6 \\
\hline Silicon & $1.0-1.1$ & no data & no data & no data & 9.0 \\
\hline Phosphorus & no data & no data & no data & 6.3 & no data \\
\hline Calcium & $0.9-1.2$ & 38.1 & 34.3 & 14.02 & 1.79 \\
\hline Iron & $55.3-56.7$ & no data & no data & 1.4 & 14.3 \\
\hline Niobium & no data & no data & no data & 0.5 & no data \\
\hline Tin & no data & no data & no data & 6.3 & 5.8 \\
\hline Platinum & no data & no data & no data & 0.9 & no data \\
\hline
\end{tabular}

iron-oxide has varying concentration and heterogeneous structure. A net formed by crossed, perpendicular tube-like elements is indistinctly visible inside the 'cloud' as well as several solid spots. This supposedly indicates some organic material within the protoconch. The connecting rings and pro-ostracum show Z, As and Ba known to be associated with fossilization of organic rich or non-biomineralized shell structures and soft tissues. These three chemical elements have maximum values in the pro-ostracum: $1.02 \%, 0.27 \%$ and $0.27 \%$, respectively. Peaks of $\mathrm{S}$ in the connecting rings and pro-ostracum possibly indicate minor amounts of barite. The gaps in the cameral deposits as well as some other structures listed above show peaks of Sn (Tables 2-4). Ba and Sn were earlier reported in the organic capsule of the Late Cretaceous belemnite Gonioteuthis Bayle 1878 (Doguzhaeva \& Bengtson 2011; fig. 2). Thus, P, Fe, $\mathrm{Ba}, \mathrm{Sn}, \mathrm{Zn}, \mathrm{As}$ and $\mathrm{S}$ are diagenetically precipitated markers of the sites originally rich in organic material.

Contrary to the shell elements discussed above, the primordial rostrum, rostrum and protoconch pockets lack $\mathrm{P}$. The primordial rostrum and rostrum show similar values of $\mathrm{C}, \mathrm{O}, \mathrm{Na}, \mathrm{Mg}$ and $\mathrm{Ca}$ (Tables 2-4); the former however shows higher 
Table 4. Chemical composition of the internal shell structures and a pro-ostracum of the Bajocian Pachybelemnopsis. (EDS data; in per cent to total weight).

\begin{tabular}{|c|c|c|c|c|c|c|c|}
\hline \multirow[b]{2}{*}{ Element } & \multicolumn{7}{|l|}{ Site } \\
\hline & $\begin{array}{l}\text { Connecting } \\
\text { ring }\end{array}$ & $\begin{array}{l}\text { Closing } \\
\text { membrane }\end{array}$ & $\begin{array}{l}\text { Organic layers of } \\
\text { protoconch wall } \\
\text { and septa }\end{array}$ & Proostracum & $\begin{array}{l}\text { Foramen of } \\
\text { closing membrane }\end{array}$ & $\begin{array}{l}\text { Filling of } \\
\text { siphuncle }\end{array}$ & $\begin{array}{l}\text { Filling of } \\
\text { protoconch } \\
\text { and first } \\
\text { chambers }\end{array}$ \\
\hline Carbon & $8.8-18.8$ & $6.7-11.9$ & $7.1-11.4$ & $7.7-11.5$ & $6.1-14.6$ & 12.5 & $11.0-15.6$ \\
\hline Oxygen & $33.7-42.7$ & $20.3-48.0$ & $30.0-54.0$ & $20.9-47.2$ & $34.3-51.7$ & $33.8-46.9$ & $38.6-56.2$ \\
\hline Fluorite & $5.3-5.6$ & $0-6.5$ & $6.1-8.1$ & no data & no data & no data & no data \\
\hline Magnesium & $0.1-0.8$ & no data & no data & $0.0-0.2$ & no data & no data & no data \\
\hline Aluminium & $0.8-1.4$ & no data & no data & $0.5-1.4$ & $1.3-1.6$ & 1. 7 & no data \\
\hline Silicon & $2.4-4.8$ & 2.2 & 1.3 & $1.5-2.7$ & $1.4-1.7$ & 1.7 & no data \\
\hline Phosphorus & $6.8-12.2$ & $6.5-16.9$ & $5.8-10.5$ & $0.1-0.2$ & no data & no data & no data \\
\hline Sulphur & $0.1-0.3$ & no data & no data & $0.1-0.2$ & no data & no data & no data \\
\hline Calcium & $23.4-29.6$ & $16.7-50.1$ & $20.6-37.2$ & $0.9-19.3$ & $2.9-43.4$ & 40.6 & $28.2-50.4$ \\
\hline Iron & $1.2-4.4$ & 30 & 9.1 & $18.4-62.9$ & $51.9-61.8$ & 62.8 & no data \\
\hline Zinc & $0.1-0.3$ & no data & no data & $0.1-1.0$ & no data & no data & no data \\
\hline Arsenic & $0.0-0.1$ & no data & no data & $0.1-0.3$ & no data & no data & no data \\
\hline Strontium & $0.9-1.23$ & no data & no data & $0.0-0.7$ & no data & no data & no data \\
\hline Niobium & $1.5-2.7$ & 3.38 & no data & no data & no data & no data & no data \\
\hline Tin & no data & 13.46 & 6.04 & no data & no data & no data & no data \\
\hline Platinum & 1.7 & $0.7-4.1$ & no data & no data & no data & no data & no data \\
\hline Barium & 0.1 & no data & no data & $0.1-0.3$ & no data & no data & no data \\
\hline
\end{tabular}
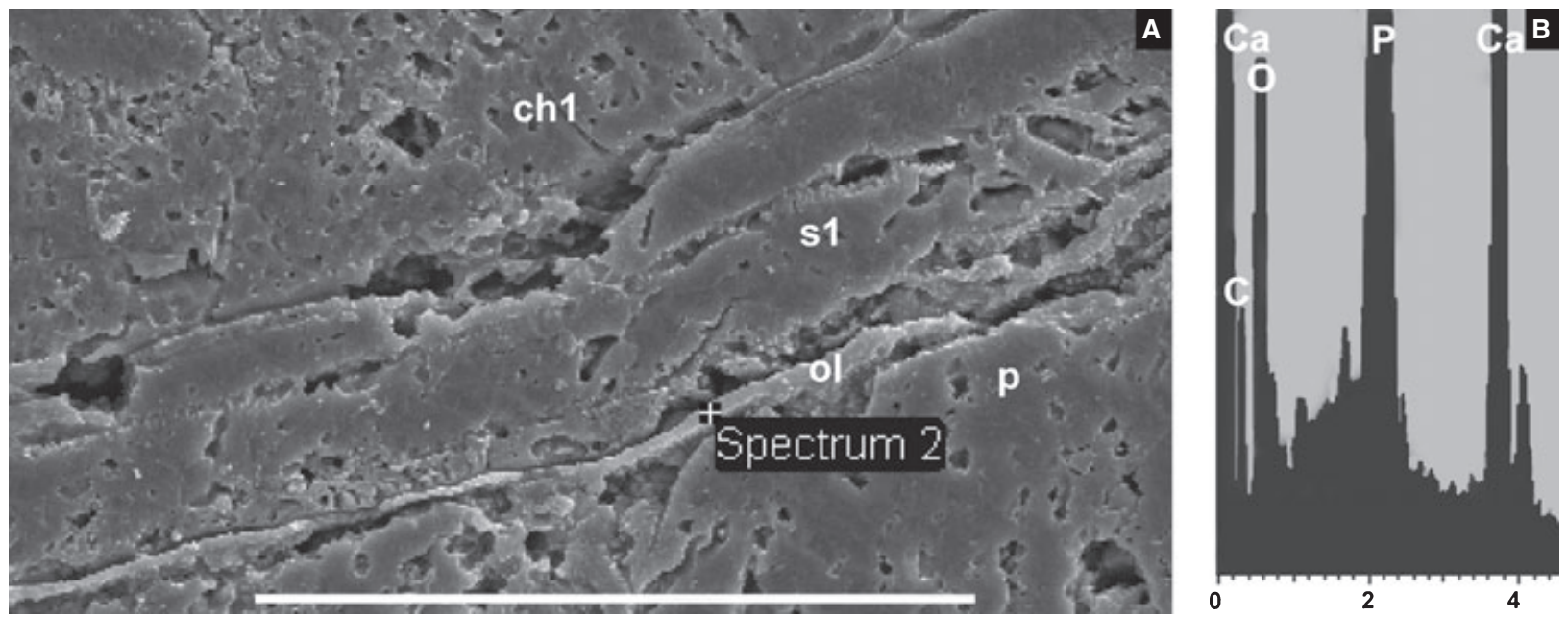

Fig. 7. Parapassaloteuthis zieteni (MNHNL BEL127), Pliensbachian, Early Jurassic; Oetrange. Energy-dispersive spectrometry data on the adapical organic layer of first septum of A, median section of the apical part of the shell with the marked point of the spectrum 2 taken. Scale bar $=50 \mu \mathrm{m}$. B, the spectrum 2 showing chemical composition of the adapical organic layer of first septum. Abbreviations: ol, organic layer of the first septum; for the other abbreviations see Fig. 2.

values of $\mathrm{N}$ and $\mathrm{Sr}$ that are three times higher than in the rostrum, but lower value of $\mathrm{K}$ (Table 2). Moreover, the primordial rostrum shows the highest, among all tested morphological structures, values of C (14.38\%), $\mathrm{N}(10.03 \%), \mathrm{O}(53.89 \%), \mathrm{Mg}$ $(0.44 \%)$ and $\mathrm{Sr}(1.28 \%)$ (Tables 2,3$)$. Nitrogen evidences non-fossilized organic material of the primordial rostrum. The protoconch pockets show peaks of $\mathrm{Si}, \mathrm{Fe}, \mathrm{Sn}, \mathrm{Al}, \mathrm{Na}$ (Table 3) apparently indicating their postmortem filling.
In Parapassaloteuthis, the comparison of chemical composition between the pro-ostracum, on the one hand, and the rostrum, primordial rostrum, and septa, on the other hand, reveals that in the pro-ostracum, the content of $\mathrm{Ca}(28.3 \%)$ is less than in the listed structures, but the content of $\mathrm{C}$ $(13 \%), \mathrm{N}(6.8 \%)$ and $\mathrm{O}(61.3 \%)$ is higher (see Table 2). These data confirm the inorganicorganic composition of the pro-ostracum (Fig. 9B-D). 


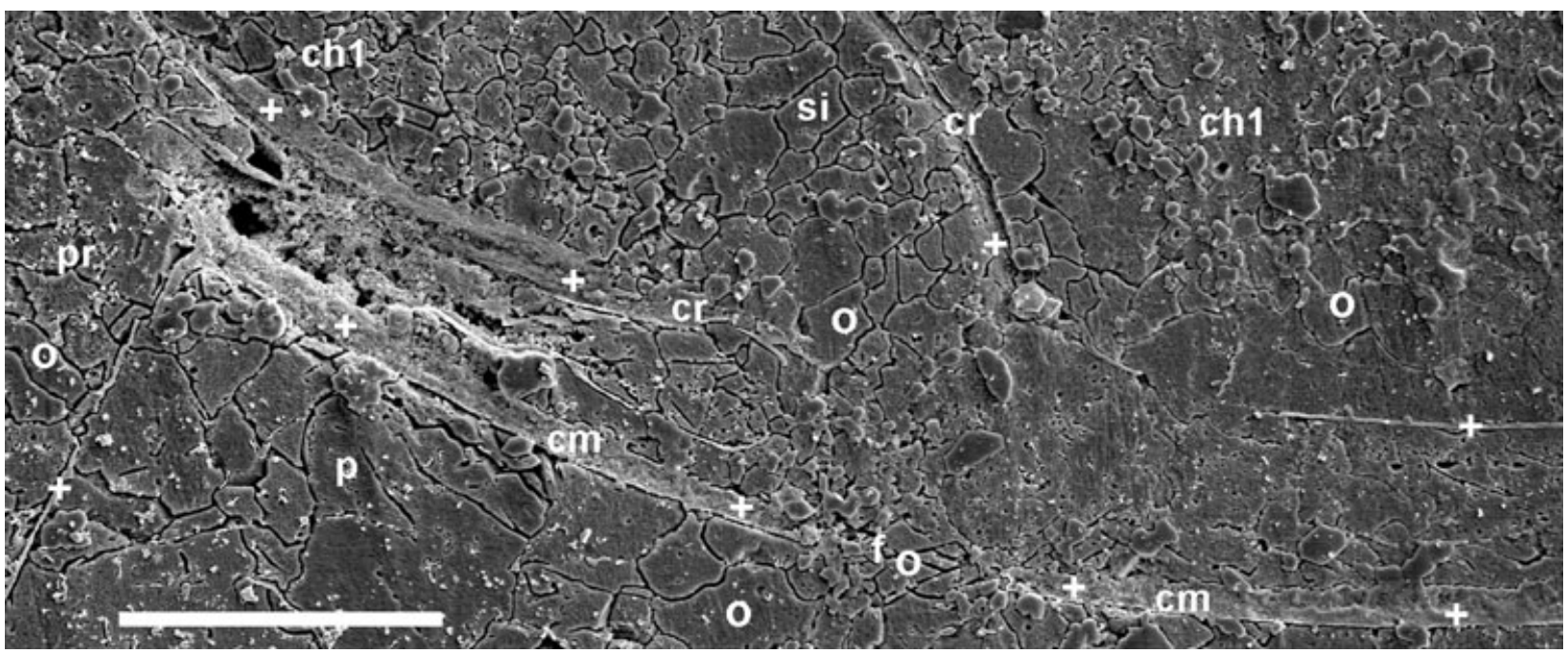

Fig. 8. Pachybelemnopsis apiciconus (MNHNL BEL237), Bajocian, Middle Jurassic; Belmont, France. Energy-dispersive spectrometry data tracing distribution of $\mathrm{P}$ along the closing membrane and indicating a foramen of the closing membrane. Scale bar $=50 \mu \mathrm{m}$. Abbreviations: +, points showing phosphorus; o, points lacking phosphorus; for the other abbreviations see Fig. 2.
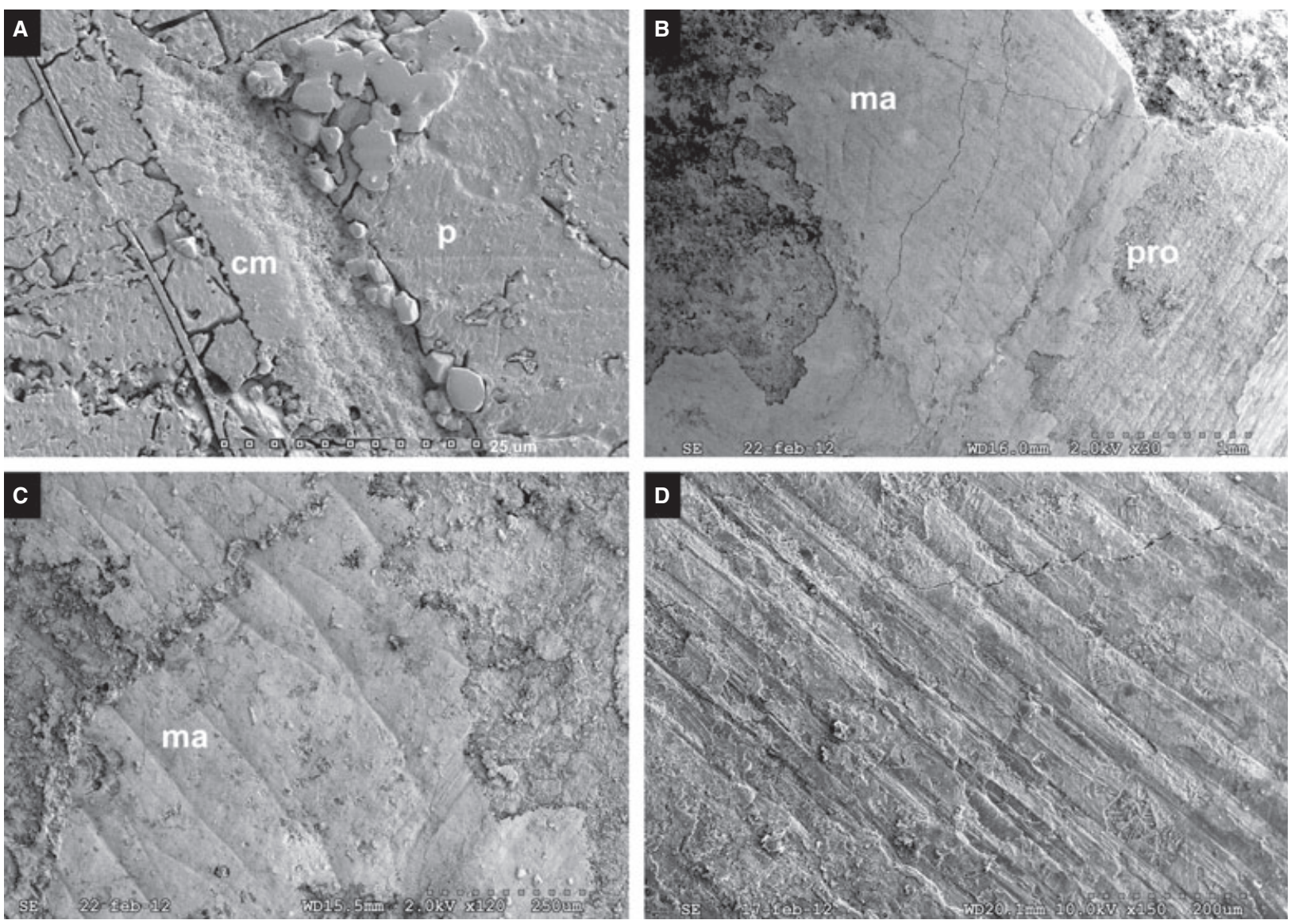

Fig. 9. A, Pachybelemnopsis apiciconus (MNHNL BEL224), Bajocian, Middle Jurassic; St. Vigor, Normandy, France. The globular ultrastructure of the closing membrane with a microbial size of globules; enlarged detail of Fig. 6C. B, C, Parapassaloteuthis zieteni (MNHNL BEL235). Late Pliensbachian, Early Jurassic; Aubange, Belgian Province of Luxembourg. Pro-ostracum showing a longitudinal striation of the lateral field (to the wright) and a criss-cross pattern of the mantle attached to the pro-ostracum (to the left). Scale bars $=1 \mathrm{~mm}$, $250 \mu \mathrm{m}, 200 \mu \mathrm{m}$, respectively. Abbreviations: ma, mantle; pro, pro-ostracum; for the other abbreviations see Fig. 2. 


\section{Discussion}

\section{Protoconch size in belemnoids}

In the evolutionary history of Belemnoidea, the approximate range of the protoconch diameter $(0.31-1 \mathrm{~mm})$ and length $(0.24-0.9 \mathrm{~mm})$ is defined by the smallest protoconchs of the Early Jurassic Nannobelus, on the one hand, and the largest protoconchs of the Early Carboniferous Hematites Flower \& Gordon 1959 (Mapes et al. 2010), Early-Middle Jurassic Dicoelites Boehm 1906 (Sachs 1961) and the Late Cretaceous Praeactinocamax Naidin 1964 (Košták \& Wiese 2008), on the other hand (Tables 1,5).

In the externally shelled bactritoids that are considered to give a rise to coleoids, the protoconch sizes, that are $0.27-1 \mathrm{~mm}$ (Doguzhaeva 2002), are close to those of the belemnoids. In extant decapods Spirula and Sepia Linné 1758, the values of the protoconch diameter and length are either like the largest values of the protoconch of belemnoids, or higher (Tables 5). It can be assumed that the protoconch size of the belemnoids might be correlated with the embryonic shell and ovum sizes. In studied belemnites, they are provisionally estimated as about $1.5-3 \mathrm{~mm}$.

Within extant non-shelled coleoids, in the ommastrephid squid Illex argentines (Castellanos 1960), which uses near-shore waters for breeding, the egg diameter differs in the populations from the shelf and the oceanic slope, being equal to $0.96-0.97 \mathrm{~mm}$ and $1.04 \mathrm{~mm}$, respectively (Castellanos 1960; Crespi-Abril et al. 2010). A similar regularity might have taken place in the belemnites under study which reveal that in Nannobelus and Parapassaloteuthis from the coastal shelves of the north-west Paris Basin, the protoconch size is smaller than in Pachybelemnopsis from the slightly deeper carbonatic ramps of the western Paris Basin. The latter genus is the only one that achieved a worldwide expansion, with the exception of the boreal areas (Doyle 1987).

Table 5. The protoconch size in different genera of belemnoids and Spirula/Sepia branch of coleoids.

\begin{tabular}{|c|c|c|c|c|}
\hline Genus & Age & $\operatorname{Dmax}(\mathrm{mm})$ & $\mathrm{L}(\mathrm{mm})$ & Reference \\
\hline Hematites & E. Carboniferous & 1 & 0.9 & Mapes et al. (2010) \\
\hline Mutveiconites & L. Carb. & 0.3 & 0.3 & Doguzhaeva (2002) \\
\hline Mutveiconites & L. Carb. & 0.5 & 0.3 & Doguzhaeva et al. (2006) \\
\hline Dictyoconites & M. Triassic & 0.5 & 0.3 & Bandel (1985) \\
\hline Metabelemnites & L. Triassic & 0.4 & 0.5 & Jeletzky (1966; pl. 3; fig. 1A) \\
\hline Aulacoceras & L. Triassic & 0.6 & 0.5 & Fuchs (2012; fig. 2D) \\
\hline Passaloteuthis & E. Jurassic & 0.5 & 0.6 & Doguzhaeva et al. (2003; figs 9, 13, 17, 19) \\
\hline Passaloteuthis & E. Jurassic & 0.6 & 0.6 & Jeletzky (1966; pl. 11; fig. 1) \\
\hline Dicoelites & E.-M. Jurassic & 1 & 0.9 & Sachs $(1961 ;$ figs 7,8$)$ \\
\hline Megateuthis & M. Jurassic & 0.7 & 0.4 & Jeletzky (1966; pl. 14; fig. 1A) \\
\hline Hibolithes & M. Jurassic & 0.4 & 0.5 & Bandel et al. (1984; fig. 1A), Ward \& Bandel (1987; fig. 17.8) \\
\hline Megateuthis & M. Jurassic & 0.5 & 0.7 & Pugaczewska (1961; 138; pl. 7, fig. 8) \\
\hline Pachybelemnopsis & M. Jurassic & - & $0.4-0.5$ & Pugaczewska (1961; 152, 160; pl. 14, fig. 6) \\
\hline Hibolithes & M. Jurassic & - & $0.4-0.8$ & Pugaczewska (1961; 167, 176; pl. 19, fig. 8) \\
\hline Pachyteuthis & L. Jurassic & 0.5 & 0.4 & L.A. Doguzhaeva, unpublished data \\
\hline Hibolithes & E. Cretaceous & $0.3-0.5$ & $0.3-0.4$ & Kabanov (1967; 36, figs 16, 17A) \\
\hline Aulacoteuthis & E. Cret. & $0.3-0.5$ & $0.3-0.4$ & Kabanov (1967; 36, figs 16-18) \\
\hline Neohibolites & E. Cret. & $0.3-0.5$ & $0.3-0.4$ & Kabanov (1967; 36, figs 17B, 18A) \\
\hline Conobelus & E. Cret. & $0.3-0.5$ & $0.3-0.4$ & Kabanov (1967; 36, fig. 18B) \\
\hline Duvalia & E. Cret. & $0.3-0.5$ & $0.3-0.4$ & Kabanov (1967: 36; fig. 18G) \\
\hline Conobelus & E. Cret. & 0.4 & 0.4 & Barskov (1973; fig. 1E) \\
\hline Mesohibolites & E. Cret. & 0.4 & 0.4 & Barskov (1973; fig. 1A) \\
\hline Mesohibolites & E. Cret. & 0.3 & 0.3 & L.A. Doguzhaeva, unpublished data \\
\hline Tauriconites & E. Cret. & $0.5-0.6$ & $0.4-0.5$ & Drushchits et al. (1984) \\
\hline Conobelus & E. Cret. & 0.3 & - & Doguzhaeva et al. (1999; fig. 1A) \\
\hline Praeactinocamax & L. Cret. & 0.9 & 0.9 & Košták \& Wiese (2008; fig. 4A) \\
\hline Gonioteuthis & L. Cret. & 0.7 & 0.5 & Doguzhaeva \& Bengtson (2011; pl. 1, fig. 1) \\
\hline Conoteuthis & L. Cret. & 0.4 & 0.5 & Fuchs et al. (2012; fig. 4D) \\
\hline Belemnitella & L. Cret. & 0.6 & 0.6 & Larson (2010) \\
\hline Groenlandibelus & L. Cret. & 0.7 & 0.6 & Jeletzky (1966; pl. 20, fig. 1A) \\
\hline Mississaepia & Eocene & 1.5 & 0.5 & Doguzhaeva et al. (in press) \\
\hline Belemnosis & Eocene & - & 1.3 & Doguzhaeva (2000) \\
\hline Spirula & Recent & - & 0.7 & \\
\hline
\end{tabular}

$\mathrm{D}$ max, maximum diameter; $\mathrm{L}$, protoconch length. 


\section{Embryonic shell structure of the Early-Middle Jurassic belemnites}

The morphology of the juvenile shells of the Pliensbachian Passaloteuthis, that have been so far known in more detail than in other belemnites, favours the idea that the embryonic shell of the Jurassic belemnites represents an internal structure consisted of the protoconch, one or two chambers of the phragmocone, and the organic-rich primordial rostrum and pro-ostracum; the latter possessing abroad central field with rounded growth rings and two narrow lateral fields with fine longitudinal striae (Doguzhaeva et al. 2003, figs 1-3).

The Passaloteuthis model is confirmed by the embryonic shell structure of the Early-Middle Jurassic belemnites from the Paris Basin herein reported (see Observations). In these belemnites, the embryonic shell is distinguished in polished median shell sections due to the ultrastructural differences between the loosely mineralized finely laminated primordial rostrum and the solid rostrum (Figs 2A; 3A-E; 4A, C, F, G; 5C; 6C). The primordial rostrum forms a capsule-like structure tightly surrounding the protoconch and the phragmocone (Fig. 4G). Non-fossilized organic component of the primordial rostrum is indicated with the detected nitrogen (Table 2) that is a reliable marker of nonfossilized organic material (Oehler et al. 2008). Among the diagenetic features suggesting the originally organic-rich composition of the primordial rostrum are caverns observed within this shell structure in the Middle Jurassic Hibolithes Dénys de Montfort 1808; (Bandel et al. 1984) and Passaloteuthis (Doguzhaeva et al. 2003). The caverns were probably formed at places of perishable material that was not preserved. The globular or ovoid protoconchs of the belemnites under study have smooth surfaces (Figs 3C; 5A); they have neither the net-like ornament of the protoconch secreted in some bactritoids (Doguzhaeva 2002), nor tubercles typical for the protoconchs of ammonoids (Landman 1988; Tanabe et al. 2010). The protoconch wall is formed by two organic layers with the prismatic layer in between (Fig. 2C); it frays out in the corners between the protoconch and the phragmocone. In Holcobelus and Pachybelemnopsis, the inner organic layer of the protoconch wall diverges from the prismatic layer and forms the lens-like compartments (Fig. 4A-E), herein named protoconch pockets, which have postmortem filling (Table 3), and therefore, in lifetime, they might contain gas or liquid with gas; this would diminish the weight of eggs and hatching. A similar structure has previously been observed in the Late Jurassic belemnite Pachyteuthis Bayle 1878 (Barskov 1973). It is not excluded that the protoconch contained during life-time organic substance that was postmortem sporadically iron-oxidized (Figs 2D, 3D; Table 3).

The observations on Nannobelus, Parapassaloteuthis, Holcobelus and Pachybelemnopsis suggest that an organic rich closing membrane is under formation. In the Early Sinemurian Nannobelus, the aperture of the protoconch seems to be covered with a perforated septum (Fig. 2A, B), like in bactritoids. The assumption that the closing membrane was formed but not preserved in the noted genus is less probable because the structures of similar composition, for instance connecting rings, are preserved in the shells that lack the closing membrane. In Parapassaloteuthis, the first septum is irregularly mineralized and has a prominent organic layer on its adapical surface (Fig. 7). In Pachybelemnopsis apiciconus, the closing membrane has a small sub-ventral foramen boarded with a retrochoanitic neck (Fig. 6A-C). The foramen of the closing membrane is ten times less than the foramen of the first septum. Besides, two more specimens of Pachybelemnopsis exhibit the foramen of the closing membrane (Figs 4A, B; 8). The latter observation suggests that the process of formation of closing membrane was not yet finished in the belemnites under study. However, a Bajocian specimen of Holcobelus from Dorset (Jeletzky 1966; pl. 25, fig. 1B) was shown to have a structure that resembles a closing membrane and '...typically developed and well preserved. However, foot of the siphuncle and proseptum almost completely obliterated.' (Jeletzky 1966, p. 96). The image on pl. 25, fig. 1B in Jeletzky (1966) shows that the interpretation of the black structure above the protoconch as a closing membrane is not the only possible one as similar black 'membranes' are present at the next septa.

The observed perforated closing membrane points out that in Pachybelemnopsis, like in Spirula, the siphuncle, or prosipho, may penetrate in the protoconch. Such a structure of the closing membrane is reported for the first time and is not typical for the closing membrane of the belemnites. The presence of the retrochoanitic neck may indicate that the closing membrane originated from the adapical organic lining of the first septum due to cancellation of the secretion of its prismatic layer. A similar idea on the origin of the closing membrane of belemnites was introduced by Bandel (1985) who thinks that it originated due to decalcification of the first prismatic septum. The development of the closing membrane in the Late Carboniferous-Triassic aulacocerids has not been yet convincingly proved and the opinions on this structure in aulacocerids are discrepant 
(Jeletzky 1966; Dauphin 1983; Bandel 1985; Fuchs 2012). The closing membrane might be absent in the Early Carboniferous Hematites (Mapes et al. 2010). The other cephalopods with a spherical protoconch - spirulids, bactritoids, ammonoids and sphaerothocerids - evidently secreted the first prismatic septum perforated with a foramen for siphuncle attached to the inner surface of the protoconch.

The embryonic shell of the studied belemnites includes one or more chambers of the phragmocone. In Nannobelus (Fig. 2A, C, F), Parapassaloteuthis, Holcobelus (Fig. 4C) and Pachybelemnopsis (Figs 4A, $5 \mathrm{C}, 6 \mathrm{~A}$ ), the first chamber is comparatively long and apparently belonged to the embryonic shell. If is supposed that the adaptation of hatchling first retarded shell growth, the first chambers of the postembryonic shell might be shorter than the chambers of the embryonic shell. The first septum has the prochoanitic septal neck, while septal necks of the next septum are retrochoanitic (Figs 2A, B; 3B; 4A, B; 6C). The siphuncle starts either like a tube (Fig. 3A, $\mathrm{B}$; 5A-D; 6C), or a foot-like structure covering the total surface of the closing membrane (Fig. 4A, B). The tube-like beginning adheres to the closing membrane. The cross-section of the tube gives an idea on the size of a permeable spot providing exchange of gas and liquid between the siphuncle and the protoconch. It is reasonable to assume that the closing membrane has a foramen in front of the tube-like beginning of the siphuncle, and the rest of the surface is not permeable. In a case of a foot-like beginning of the siphuncle, the permeable area is essentially larger than in the previous case of a tubelike beginning of the siphuncle.

In studied shells, the pro-ostracum is recognized on the phragmocone surface in adult shells of Parapassaloteuthis (Fig. 9B-D) and Pachybelemnopsis; it shows irregular mineralization indicating its organic rich original composition (Tables 2,4 ). These observations, together with earlier obtained data on the organic-rich composition of the pro-ostracum in the Sinemurian Nannobelus (Doguzhaeva 2012), are extrapolated on the composition of the proostracum of the embryonic shell.

Thereby, it is suggested that, due to the proostracum, primordial rostrum, and closing membrane which are rich in organic matter, possibly in chitin, the embryonic shell of the Early-Middle Jurassic belemnites was transformed into light but mechanically strong inorganic-organic structure. The inorganic-organic shell is secreted, for instance, in extant Sepia; the chitin-protein complex makes up about $10 \%$ of total weight of the cuttlebone (Florek et al. 2009). The chitin compatible material was detected in the Eocene cuttlebone as well (Weaver et al. 2011; Doguzhaeva et al. in press). The increasing of the organic component of the shell matter took place in the Late Cretaceous belemnite Gonioteuthis secreted the organic capsule around the protoconch and phragmocone (Doguzhaeva \& Bengtson 2011).

The inorganic-organic embryonic shell, with a properly protected protoconch of the Early-Middle Jurassic belemnites, possibly allowed the hatching of the eggs in greater depths and lower temperatures, in some degree, like in Sepia. This is due to the characteristic properties of the chitin that is light, mechanically strong, physiologically inert natural shell matter broadly using for protection and support in invertebrate animals. Such an embryonic shell structure might also accelerate the adaptation of hatchlings to a nektonic mode of life and allowed easy migration of juveniles and adults down into deep and cold waters and come back to warmer waters. Sepia usually migrates to deeper water in winter and can move rapidly when needed. Cuttlefishes reveal diverse skeletal morphology enabling representatives of this taxon to occupy a range of depths and habitats (Sherrard 2000). This may be one of the factors contributing to higher species diversity in the latter group, comprising about 120 species (Reid et al. 2005). The increase in the taxonomic diversity of the Early-Middle Jurassic belemnites might be also determined by the increasing ability to occupy a broad range of depths along the coastal shelves. Therefore, the structure of the embryonic shell developed in the Early and Middle Jurassic belemnites might be of major significance in the process of colonization of a broad range of depths along the coastal shelves and broadening of geographical distribution and increasing diversification of belemnites in Early-Middle Jurassic.

Acknowledgements. - This study was carried out thanks to support by the Royal Swedish Academy of Sciences and personally by Prof. Jan Bergstrom and Prof. Stefan Bengtson, Department of Palaeozoology of the Swedish Museum of Natural History. Jan Strugnell (Australia) donated several shells of Nannobelus collected during the Third International Symposium 'Coleoids through time', Luxembourg. Neil Landman (American Museum of Natural History, New-York, USA) made stylistic corrections to the previous version of the study. We are indebted to all these persons; also we are grateful to Martin Košták and the anonymous reviewer for help with improving this article.

\section{References}

Bandel, K. 1985: Composition and ontogeny of Dictyoconites (Aulacocerida, Cephalopoda). Paläontologische Zeitschrift 59, 223-244.

Bandel, K. \& Boletzky, S.V. 1979: A comparative study of the structure, development and morphological relationship of chambered cephalopod shells. The Veliger 21, 313-354. 
Bandel, K. \& Stinnesbeck, W. 2006: Naefia Wetzel 1930 from the Quiriquina Formation (Late Maastrichtian, Chile): relationship to modern Spirula and ancient Coleoidea (Cephalopoda). Acta Universitatis Carolinae - Geologica 49, 21-32.

Bandel, K., Engeser, T. \& Reitner, J. 1984: Die Embryonalentwicklung von Hibolithes (Belemnitida, Cephalopoda). Neues Jahrbuch für Geologie und Paläontologie 167, 275-303.

Barskov, I.S. 1973: About a structure of the protoconch and ontogeny of belemnites (Coleoidea, Cephalopoda). Doklady Akademii Nauk SSSR 208, 439-442. [In Russian].

Bayle, E. 1878: Fossiles principaux des terrains. Explication de la carte géologique de la France 4, atlas, pls.1-157. Imprimerie Nationale, Paris.

Blainville, H.M.D. de 1827: Mémoire sur les Belemnites considerées zoologiquement etgéologiquement. 136 pp. Levrault, Paris.

Boehm, G. 1906: Geologische Mitteilungen aus dem Indo-australischen Archipel. 1. Neues aus dem Indo-australischen Archipel. Neues Jahrbuch für Geologie, Mineralogie und Paläontologie - Abhandlungen 22, 385-412.

Boulvain, F., Belanger, I., Delsate, D., Dosquet, D., Ghysel, P., Godefroit, P., Laloux, M., Roche, M., Teerlynck, H. \& Thorez, J. 2001: New lithostratigraphical, sedimentological, mineralogical and palaeontological data on the Mesozoic of Belgium Lorraine: a progress report. Geologica Belgica 3, 3-33.

Castellanos, Z.J.A.de. 1960: Una nueva especie de calamar Argentino Ommastrephes argentinus sp. nov. (Mollusca, Cephalopoda). Neotropica (La Plata) 6, 55-58.

Chen, T.E. 1982: Mesozoic coleoidea fauna from Xizang. Paleontology of Xizang 4, 280-325.

Chen, T.E. \& Sun, Z.H. 1982: Discovery of Permian belemnoids in South China with comments on the origin of the Coleoidea. Acta Palaeontological Sinica 21, 181-190.

Crespi-Abril, A., Dellatorre, F. \& Barón, P. 2010: On the presence of Illex argentinus (Castellanos, 1960) (Cephalopoda: Ommastrephidae), paralarvae and juveniles in near-shore waters of Nuevo Gulf, Argentina. Latin American Journal of Aquatic Research 38, 297-301.

Dauphin, Y. 1983: Les subdivisions majeures de la classe Céphalopodes: bases de la systématique actuelle - apport de l'analyse microstructurale. Thèse Universitè de Paris-Sud, Bulletin de la Société Géologique de France, 284 pp. Paris.

Delsate, D. 2008: Lower Sinemurian coleoids at Metzert-Tontelange (Belgian Province of Luxembourg). 141-145. In Musée national d'histoire naturelle de Luxembourg (ed.): Third International Symposium Coleoid cephalopods Through Time, Luxembourg 08 - 11. 10. 2008. National Museum of Natural History. 148 pp.

Dénys de Montfort, D. 1808: Conchyliologie systematique, et classification methodique des Coquilles. In Schoell, F. (ed.): Coquilles univalves, cloisonnées, Vol. 1, 410 pp. Schoell, Paris.

Diekmann, R., Piatkowski, U. \& Schneider, M. 2002: Early life and juvenile cephalopods around seamounts of the subtropical eastern North Atlantic: illustrations and a key for their identification. Berichte aus dem Institut für Meereskunde an der Christian-Albrechts-University of Kiel, Germany 326, 1-42.

Doguzhaeva, L.A. 2000: The evolutionary morphology of siphuncular tube in Spirulida (Cephalopoda; Coleoidea). Revue de Paléobiologie, Genève, Mémoire Spécial No. 8. 83-94.

Doguzhaeva, L.A. 2002: Adolescent bactritoid, orthoceroid, ammonoid and coleoid shells from the Upper Carboniferous and Lower Permian of south Urals. Abhandlungen der Geologischen Bundesanstalt Wien 57, 9-55.

Doguzhaeva, L.A. 2012: The original composition of the pro-ostracum of an Early Sinemurian belemnite from Belgium deduced from mode of fossilization and ultra-structure. Palaeontology 55, 249-260.

Doguzhaeva, L.A. \& Bengtson, S. 2011: The capsule: an organic skeleton structure in the Late Cretaceous belemnite Gonioteuthis from North-West Germany. Palaeontology 54, 397-415.

Doguzhaeva, L.A. \& Summesberger, H. 2012: Pro-ostraca of Triassic belemnoids (Cephalopoda) from Northern Calcareous Alps, with observations on their mode of preservation in an environment of northern Tethys which allowed for carbonization of non-biomineralized structures. Neues Jahrbuch für Geologie und Paläontologie-Abhandlungen 266, 31-38.

Doguzhaeva, L.A., Mutvei, H., Kabanov, G.K. \& Donovan, D.T. 1999. Conch ultrastructure and septal neck ontogeny of the belemnite Conobelus (Duvaliidae) from the Valanginian of the Crimea (Black Sea). 223-232. In Oloriz, F. \& Rodriguez-Tovar, F.J. (eds): Advancing Research on Living and Fossil Cephalopods, 550 pp. Klumer Academic/Plenum Publishers, New-York, Boston, Dordrecht, London, Moscow.

Doguzhaeva, L.A., Mutvei, H. \& Weitschat, W. 2003: The pro-ostracum and primordial rostrum at early ontogeny of Lower Jurassic belemnites from north-western Germany. Berliner Paläobiologische Abhandlungen 3, 79-89.

Doguzhaeva, L.A., Mapes, R.H. \& Dunca, E. 2006: A Late Carboniferous adolescent cephalopod from Texas (USA), with a short rostrum and a long body chamber. Acta Universitatis Carolonae-Geologica 49, 55-68.

Doguzhaeva, L.A., Weaver, P.G. \& Ciampaglio, C.N. in press: A unique late Eocene coleoid cephalopod Mississaepia from Mississippi, USA: New data on cuttlebone morphology, ultrastructure, chemical composition, and their phylogenetic implications. Acta Palaeontologica Polonica, doi:10.4202/app. 2011.0208.

Doyle, P. 1987: Lower Jurassic-Lower Cretaceous belemnite biogeography and the development of the Mesozoic boreal realm. Palaeography, Palaeoclimatology, Palaeoecology 61, 237-254.

Doyle, P., Kelly, S.R.A., Pirrie, D. \& Riccardi, A.C. 1997: Jurassic belemnite distribution patterns: implications of new data from Antarctica and Argentina. Alcheringa 21, 219-228.

Drushchits, V.V., Kabanov, G.K. \& Nerodenko, V.M. 1984: The structure of the protoconch and rostrum in Tauriconites gen. nov. (Coleoidea, Diplobelida). Palaeontologicheskij zhurnal 1, 12-18. [In Russian].

Florek, M., Formal, E., Gómez-Romero, P., Zieba, E., Paszkowicz, W., Lekki, J., Nowak, J. \& Kuczumow, A. 2009: Complementary microstructural and chemical analyses of Sepia officinalis endoskeleton. Materials Science and Engineering: C, Biomimetic and Supramolecular Systems 29, $1220-1226$.

Flower, R.H. \& Gordon, M.J.R. 1959: More Mississippian belemnites. Journal of Paleontology 33, 809-842.

Fuchs, D. 2012: The 'rostrum'- problem in coleoid terminology - an attempt to clarify inconsistencies. Geobios 45, 29-39.

Fuchs, D., Keupp, H. \& Wiese, F. 2012: Protoconch morphology of Conoteuthis (Diplobelida, Coleoidea) and its implications on the presumed origin of the Sepiida. Cretaceous Research 34, 200-207.

Grossouvre, A.de. 1919: Bajocien-Bathonien dans la Nièvre. Bulletin de la Société Géologique de France 4, 337-459.

Gustomesov, V.A. 1977: Revision of Jurassic belemnites. Bulletin of Moscow Society of ispytatelej prirody, Section Geology 52, 103-117. [In Russian].

Hanai, T. 1953: Lower Cretaceous belemnites from Miyako District, Japan. Japanese Journal of Geology and Geography 23, 6380 .

Hewitt, R.A. \& Jagt, J.W.M. 1999: Maastrichtian Ceratisepia and Mesozoic cuttlebone homeomorphs. Acta Palaeontologica Polonica 44, 305-326.

Iba, Y., Sano, S., Mutterlose, J. \& Kondo, Y. 2012: Belemnites originated in the Triassic - a new look at an old group. Geology 40, 911-914.

Jeletzky, J.A. 1966: Comparative Morphology, Phylogeny, and Classification of Fossil Coleoidea. University of Kansas Paleontological Contributions, Mollusca, Article 7, 162 pp.

Kabanov, G.K. 1967: The skeleton of belemnitids; its morphology and biological analysis. Trudy Paleontologicheskogo Instityta USSR Academy of Sciences 114, 117 pp. [In Russian].

Košták, M. \& Wiese, F. 2008: Lower Turonian record of belemnite Praeactinocamax from NW Siberia and its palaeogeographic significance. Acta Palaeontologica Polonica 53, 669678. 
Lamarck, J.B.P.A. 1799: Prodr ${ }^{\circ}$ me d'une nouvelle classification des coquilles, comprenant une rédaction appropriée des caractéres génériques, et l'établissement d'un grand nombre de genres nouveaux. Mémoires de la Sociétéd'histoire naturelle de Paris 1, 63-91.

Landman, N. 1988: Early ontogeny of Mesozoic ammonites and nautiloids. 215-228. In Wiedmann J. \& Kullmann J. (eds): Cephalopods - Present and Past, 765 pp. Schweizerbart'sche Verlangsbuchhandlung, Stuttgart.

Larson, N.L. 2010: Fossil coleoids from the Late Cretaceous (Campanian \& Maastrichtian) of the Western Interior. Ferrantia $59,78-113$

Lathuilière, B. 2010. Jurassic. Eastern Paris Basin. 858-864. In McCann, T. (ed.): The Geology of Central Europe. Volume 2: Mesozoic and Cenozoic, 1449 pp. The Geological Society, London.

Linné, C. 1758: Systema naturce per regna tria nature, secundum classes, ordines, genera, species, cum characteribus, differentiis, synonymis, locis. Systema naturce per regna tria nature, secundum classes, ordines, genera, species, cum characteribus, differentiis, synonymis, locis. First volume, 10th revised edition, 824 pp. Salvius, Stockholm,

Lissajous, M. 1915: Quelques remarques sur les bélemnites jurassiques. Bulletin de la Société d'Histoire naturelle de Mâcon 6, $1-32$.

Mapes, R.H., Doguzhaeva, L.A., Mutvei, H., Landman, N. \& Tanabe, K. 2010: The oldest known (Lower Carboniferous Namurian) protoconch of a rostrum-bearing coleoid (Cephalopoda) from Arkansas, USA: phylogenetic and paleobiologic implications. Ferrantia 59, 114-125.

Mariotti, N., Santantonio, M. \& Weis, R. 2010: New data on the paleobiogeographic and biostratigraphic distribution of Holcobelus Stolley, 1927 and its allies (Belemnitida) in the Middle Jurassic. Ferrantia 59, 137-147.

Mayer-Eymar, K. 1884: Die Filiation der Belemnites acuti. Vierteljahresschrift der naturforschenden Gesellschaft, Zürich 1884, $41-56$.

Meyer, J.C. 1993: Un nouveau coleoide Sepioide. Ceratisepia elongate nov. gen., nov. sp. du Paléocéne inférieur (Danien) de Vigny. Implications taxonomiques et phylogénétiques. Geobios, Mémoire Spécial 15, 287-304.

Müller-Stoll, H. 1936: Beiträge zur Anatomie der Belemnoidea. Nova Acta Leopoldina, N.F. 4, 159-217.

Naef, A. 1922: Die fossilen Tintenfische, 322 pp. Gustav Fischer Jena.

Naidin, D.P. 1964: Upper Cretaceous belemnites from the Russian Platform and adjacent areas: Actinocamax, Gonioteuthis, Belemnellocamax, 190 pp. Moscow State University, Moscow. [In Russian].

Oehler, D.Z., Robert, F., Mostefaoui, S., Meibom, A., Selo, M., Mckay, D.S. \& Gibson, E.K. 2008: Nanoisms opens a new window for deciphering organic matter in terrestrial and extraterrestrial samples. 3-23. In Seckbach J. \& Walsh M. (eds): From fossils to astrobiology. Records of Life on Earth and Search for Extraterrestrial Biosignatures. 546pp. Springer.

Pavlow, A.P. 1914: Jurassic and Lower Cretaceous Cephalopods of north Siberia. Zapiski Imperatorskoj Akademii Nauk, Phiziko-Matematicheskoe Otdelenie 21, 1-68. [In Russian].

Pomérol, C. 1974: Le bassin de Paris. 230-258. In Debelmas, J. (ed.): Géologie de la France volume 1. Vieux Massifs et Grands Bassins Sédimentaires, 293 pp. Doin, Paris.
Préat, A., Mamet, B., De Ridder, C., Boulvain, F. \& Gillan, D. 2000: Iron bacterial and fungal mats, Bajocian stratotype (Mid-Jurassic, northern Normandy, France). Sedimentary Geology 137, 107-126.

Prell, H. 1921: Ûber die Schale von Spirula und ihren Verwandten. Centralblatt für Mineralogie, Geologie, Paläontologie 183190, 215-222.

Pugaczewska, H. 1961: Belemnoids from the Jurassic of Poland. Acta Palaeontologica Polonica 6, 105-236.

Quenstedt, F.A.von. 1845-1849: Petrefaktenkunde Deutschlands. Die Cephalopoden. 1. Tübingen, $580 \mathrm{pp}$.

Reid, A., Jereb, P. \& Roper, C.F.E. 2005: Family Sepiidae. 56-62. In Jereb P., Roper C.F.E. (eds): Cephalopods of the World. An Annotated and Illustrated Catalogue of Species Known to Date. Volume 1. Chambered Nautiluses and Sepioids (Nautiloidea, Sepiidae, Sepiolidae, Sepiadariidae, Idiosepiidae and Spirulidae). FAO Species Catalogue for Fishery Purposes 4, 1,262 pp. Rome.

Riegraf, W. 1980: Revision der Belemniten des Schwläbischen Jura. Palaeontographica, Abhandlungen A 169, 128-208.

Sachs, V.N. 1961: Some questions on Jurassic palaeogeography connected to the study of the belemnite faunas of Siberia. Geology and Geophysics 10, 74-88. [In Russian].

Sherrard, K.M. 2000: Cuttlebone morphology limits habitat depth in eleven species of Sepia (Cephalopoda: Sepiidae). The Biological Bulletin 198, 404-414.

Simpson, M. 1855: The Fossils of the Yorkshire Lias, Described from Nature, 1st edn. 149 pp. Whittaker \& Company, London/ Whitby.

Stolley, E. 1911: Beiträge zur Kenntnis der Cephalopoden der Nordeutschen Unteren Kreide. I. Die Belemnitiden der Norddeuschen Untered Kreide. I. Die Belemnitiden des Norddeutschen Gaults (Aptiens und Albiens). Geologie und Paläontologie Abhandlungen, N.F. 10, 203-272.

Stolley, E. 1927: ZurSystematik und Stratigraphie mediangefurchter Belemniten. Niedersächsischer geologischer Verein Hannover, Jahresbericht 20, 111-136.

Tanabe, K., Kulicki, C., Landman, N. \& Kaim, A. 2010: Tuberculate micro-ornamentation on embryonic shells of Mesozoic ammonoids: microstructure, taxonomic variation, and morphogenesis. 105-125. In Tanabe K., Shigeta Y., Sasaki T. \& Hirano H. (eds): Cephalopods - Present and Past, 314 pp. Tokai University Press, Tokyo.

Ward, P. \& Bandel, K. 1987: Life history strategies in fossil cephalopods. 329-350. In Boyle, P.A. (ed.): Cephalopod Life Cycles 2, 441 pp. Academic Press, London.

Weaver, P.G., Doguzhaeva, L.A., Lawver, D.R., Tacker, R.C., Ciampaglio, C.N., Crate, J.M. \& Zheng, W. 2011: Characterization of organics consistent with $\beta$-chitin preserved in the late Eocene cuttlefish Mississaepia mississippiensis. PLoS One 6, e28195, 1-9.

Weis, R. \& Delsate, D. 2005: Présence de Bélemnites précoces dans l'Hettangien de Belgique. In Delsate, D. (ed.): Biostratigraphie et Paléontologie de l'Hettangien en Belgique et au GrandDuché de Luxembourg. Royal Institute of Natural Sciences. Memoirs of the Geological Survey of Belgium 51, pp. 27-31.

Weis, R. \& Delsate, D. 2006: The earliest belemnites: new records from the Hettangian of Belgium and Luxembourg. Acta Universitatis Carolinae - Geologica 49, 181-184.

Zhu, K.Y. \& Bian, Z. 1984: Sinobelemnitidae, a new family of Belemnitida from the Upper Triassic of Longmenshan, Sichuan. Acta Palaeontologica Sinica 23, 300-319. 